\title{
Review
}

\section{Targeted Therapies for Multiple Myeloma}

\author{
Christopher Chang-Yew Leow and Michael Sze Yuan Low *
}

Monash Haematology, 246 Clayton Road, Clayton, VIC 3168, Australia; chris.leow@monashhealth.org

* Correspondence: Michael.Low@monashhealth.org

\begin{abstract}
Multiple myeloma continues to be a challenging disorder to treat despite improved therapies and the widespread use of proteasome inhibitors and immunomodulatory drugs. Although patient outcomes have improved, the disease continues to invariably relapse, and in the majority of cases, a cure remains elusive. In the last decade, there has been an explosion of novel drugs targeting cellular proteins essential for malignant plasma cell proliferation and survival. In this review, we focus on novel druggable targets leading to the development of monoclonal antibodies and cellular therapies against surface antigens (CD38, CD47, CD138, BCMA, SLAMF7, GPRC5D, FCRH5), inhibitors of epigenetic regulators such as histone deacetylase (HDAC), and agents targeting anti-apoptotic (BCL-2), ribosomal (eEF1A2) and nuclear export (XPO1) proteins.
\end{abstract}

Keywords: multiple myeloma; therapeutic targets; monoclonal antibody

check for updates

Citation: Leow, C.C.-Y.; Low, M.S.Y. Targeted Therapies for Multiple Myeloma. J. Pers. Med. 2021, 11, 334. https://doi.org/10.3390/jpm11050334

Academic Editor: Stephen Opat

Received: 22 February 2021

Accepted: 19 April 2021

Published: 23 April 2021

Publisher's Note: MDPI stays neutral with regard to jurisdictional claims in published maps and institutional affiliations.

Copyright: (c) 2021 by the authors. Licensee MDPI, Basel, Switzerland. This article is an open access article distributed under the terms and conditions of the Creative Commons Attribution (CC BY) license (https:// creativecommons.org/licenses/by/ $4.0 /)$.

\section{Basic Biology of Plasma Cell Neoplasms}

Multiple myeloma (MM) is a neoplastic disorder characterised by the abnormal proliferation of antibody-secreting plasma cells (PCs). The malignancy is part of a heterogeneous spectrum of disorders ranging from the indolent pre-cursor condition, monoclonal gammopathy of undetermined significance (MGUS), to the highly aggressive plasma cell leukaemia [1]. Whilst early stages of the disease are asymptomatic, progression is heralded by end-organ symptoms, including hypercalcaemia, renal failure, anaemia and lytic lesions.

Symptomatic MM is thought to evolve from the expansion of altered clones that are already present within the precursor MGUS. Although these initial events may generate a malignant clone, a "second" hit such as dysregulation of cell cycle control, evasion of normal apoptotic pathways or stimulation by the abnormal bone marrow (BM) microenvironment are required for myelomagenesis [2,3]. Karyotypic abnormalities account for the majority, if not all, of the initiating events, with a significant proportion identified in MGUS patients [4]. A dichotomy of genetic aberrations is observed. The first group is hyperdiploid (near double the number of normal chromosomes) with a specific genotype involving aneuploidy of several odd-numbered chromosomes, including 3, 5, 7, 9, 11 and 21. The second group involves translocations of the IgH locus at chromosome 14q. These translocations juxtapose the IgH promoter to one of many oncogenes, including three Cyclin D genes (CCND1-3), WHSC1 (MMSET), MAF or MAFB [5].

Progression of MGUS to MM is regularly accompanied by secondary genetic events such as Myc translocations (chromosome 8q42), leading to increased cell cycling and proliferation, the loss of cell cycle arrest signals including $p 53$ (deletion 17p) and CDKN2C (deletion 1p), and genetic aberrations with less understood consequences such as deletion $13 q$ and amplification $1 q[5,6]$. Additionally, aberrant NFKB and Ras signalling are a relatively common event in MM and arise from a broad mutation spectrum that provides a myriad of pro-survival and growth signals to MM cells [7-9]. Although these genetic alterations appear to be the drivers of tumorigenesis, they manifest in different phenotypes under the influence of epigenetic mechanisms. Such epigenetic changes involve DNA methylation and primarily occur on $\mathrm{CpG}$ dinucleotides [10]. Increasing evidence demonstrates that dysregulation of epigenetic regulators such as EZH2, DNMT3A and his- 
tone deacetylases (HDACs) promote and contribute to the complexity of myelomagenesis, whilst also providing potential therapeutic targets [11-13].

Lastly, interactions between malignant PCs and the bone marrow (BM) milieu promote malignant transformation and propagation. IL-6 has been demonstrated to be an essential promoter of malignant PC survival and an inhibitor of apoptosis via numerous pathways, such as upregulation of the pro-survival proteins, BCL-xL and MCL-1 [14,15]. Dysregulation of other cytokines in the BM microenvironment results in angiogenesis (VEGF), evasion of cell-mediated immunity (TNF-alpha and IL-12) and escape from pro-apoptotic pathways (PDGF, IGF-1) [16]. These cytokines and soluble factors all provide potential targets for drug therapy.

\section{Standard-of-Care Therapy for Multiple Myeloma}

With expanding knowledge of PC and myeloma biology, treatment of MM has become more effective. The advent of proteasome inhibitors (PIs) and immunomodulatory drugs (IMiDs) has markedly improved the response rates and significantly increased survival in MM patients [17]. PIs (such as bortezomib) prevent the degradation of misfolded proteins via the proteasome, resulting in their accumulation within a malignant PC and eventual cell death due to the unfolded protein response [18]. The proteasome is also involved, with additional cellular functions, including the regulation of signalling pathways, cell cycle and DNA repair [19], hence, PIs may promote MM cell death through a variety of mechanisms. IMiDs (such as thalidomide and lenalidomide) function by altering the target specificity of CUL4A-DDB1-Cereblon E3 ubiquitin ligase, which in MM, leads to the degradation of two key PC transcription factors, Ikaros (IKZF1) and Aiolos (IKZF3) [20,21]. IMiD-mediated degradation of IKZF1 and IKZF3 results in a reduction in IRF4, a key mediator of the oncogene MYC [22]. Furthermore, IKZF1 and IKZF3 degradation results in $\mathrm{MM}$ cell growth arrest and the activation of T-cells, both of which contribute to the anti-myeloma effect of IMiDs [20,21].

Combinations of these agents form the pillars of frontline treatment of MM. Three drug regimens utilising bortezomib, dexamethasone and an additional agent, such as cyclophosphamide (VCd), thalidomide (VTd) or lenalidomide (RVd), are the standard of care prior to autologous stem cell transplantation (ASCT), which utilises a melphalan-based conditioning regimen [23]. Following ASCT, bortezomib- or lenalidomide-based maintenance therapy is commenced to prolong response, slow progression and improve overall survival [24-26]. Patients ineligible for an ASCT are still evaluated for induction with bortezomib, lenalidomide or an alkylating-agent based regimen. Newer PIs (carfilzomib, ixazomib) and IMiDs (pomalidomide) have demonstrated improved progression-free survival (PFS) and overall survival (OS) in an assortment of regimens in relapsed/refractory MM (RRMM) patients [27-30]. Further novel PIs (maprozomib, oprozomib) are also currently being investigated [31]. However, in the absence of a cure, malignant PC clones evolve to become increasingly aggressive and refractory to PI and IMiD therapies, culminating in disease relapse, progression and death.

\section{Novel Therapies}

\subsection{Monoclonal Antibodies Targeting Cell Surface Antigens}

\subsubsection{CD38}

CD38 is a type II transmembrane glycoprotein whose ascribed functions include receptor-mediated adhesion, signal transduction in lymphoid and myeloid cells and bifunctional ecto-enzymatic activities that modulate intracellular calcium mobilization [32]. CD38 is expressed at minimal levels on normal lymphoid and myeloid cells and in some non-haematopoietic tissues as well as red blood cells [33]. The high expression of CD38 on malignant plasma cells in $\mathrm{MM}$ and its role in cell signalling have made it an attractive antibody target [34].

Daratumumab is a human IgG1 $\mathrm{k}$ antibody directed against a unique CD38 epitope [35]. The anti-myeloma activity of daratumumab is mediated by a diverse range of mech- 
anisms including antibody-dependent cellular cytotoxicity (ADCC) and phagocytosis, complement-dependent cytotoxicity (CDC), apoptosis and inhibition of the enzymatic effects of CD38 [36]. Rapid FDA approval of daratumumab occurred in 2016 following the results of two phase I/II clinical trials using single-agent daratumumab in RRMM [37,38]. The final analysis of patients enrolled in these studies demonstrated an overall response rate (ORR) of 31.1\%, a median duration of response (DOR) of 7.6 months and a median PFS and OS of 4.0 months and 20.1 months, respectively [39]. Subsequently, daratumumab has been investigated in conjunction with established combinations of anti-myeloma therapies.

The addition of daratumumab to PIs was investigated in the phase III CASTOR trial which analysed the effect of the addition of daratumumab to bortezomib and dexamethasone (DVd versus $\mathrm{Vd}$ ) in $498 \mathrm{RRMM}$ patients. The ORR was higher in the daratumumab group $(82.9 \%$ versus $63.2 \%, p=0.001)$ [40]. Longer term follow-up revealed that the addition of daratumumab led to improved progression-free survival (16.7 vs. 7.1 months; $p<0.0001)$. Infusion-related reactions associated with daratumumab treatment were common $(45.3 \%)$, predominantly grade $1 / 2(91.4 \%)$, and the majority occurred during the first infusion (98.2\%). Subgroup analysis of the CASTOR trial based on cytogenetic risk has demonstrated that DVd prolonged the median PFS in patients with standard (16.6 vs. 6.6 months; $p<0.0001)$ and high (12.6 vs. 6.2 months; $p=0.00106)$ cytogenetic risks. Overall, DVd achieved deeper responses with higher rates of MRD negativity and sustained MRD negativity regardless of cytogenetic risk [41]. The addition of daratumumab to carfilzomib (CANDOR and EQUULEUS trial) has also been demonstrated to improve PFS [42,43].

Similar studies combining daratumumub and IMiDs have shown equally impressive results with the phase III POLLUX study comparing the addition of daratumumab to lenalidomide and dexamethasone (DRd versus Rd) in 569 patients with RRMM [44]. After 44.3 months median follow-up, DRd versus Rd demonstrated higher ORR $(92.9 \%$ vs. $76.4 \% ; p<0.0001)$ and median PFS (44.5 vs. 17.5 months; $p<0.0001)$. Deeper responses, including CR or better $(56.6 \%$ vs. $23.2 \% ; p<0.001)$ and MRD negativity $\left(10^{-5} ; 30.4 \%\right.$ vs. $5.3 \% ; p<0.0001$ ) were observed. The addition of daratumumab to other IMiDs has been evaluated in the phase II MM-014 trial, which showed an impressive ORR of 77.7\% with daratumumab plus pomalidomide and dexamethasone (Pd), with all patients having received lenalidomide in their most recent prior regimen (75\% lenalidomide refractory) [45]. Recent data from the APOLLO study utilizing subcutaneous daratumumab in conjunction with Pd have demonstrated a similar benefit, with a reduction in risk of progression or death by $37 \%$ in RRMM [46]. Evidence suggests that treatment of MM with IMiDs leads to a transcriptional upregulation of CD38 resulting in increased CD38 cell surface expression, allowing for increased ADCC and NK cell killing with daratumumab [47]. This transcriptional change makes the combination of IMiDs and CD38 antibodies a particularly attractive therapy for MM patients.

Given its success in RRMM, the addition of daratumumab has recently been evaluated as part of upfront therapy for newly diagnosed myeloma. The ALCYONE trial compared the addition of daratumumab to bortezomib, melphalan and dexamethasone (D-VMP vs. VMP) in 706 newly diagnosed MM patients not eligible for autologous bone marrow transplantation [48]. The addition of daratumumab demonstrated an improved ORR $(90.9 \%$ vs. $73.9 \% ; p<0.0001)$. Additionally, at median follow-up of 40.1 months D-VMP showed improved PFS and OS (36-month estimate: $78.0 \%$ vs. $67.9 \% ; p=0.0003$ ) when compared to VMP alone. Undertaken in a different patient group, the CASSIOPEIA trial compared the addition of daratumumab to bortezomib, thalidomide and dexamethasone (D-VTD vs. VTD) as pre-transplant induction and as post-transplant consolidation in 1085 transplanteligible newly diagnosed myeloma patients [49]. Whilst the addition of daratumumab led to no statistically significant change in ORR, a higher number of patients achieving a complete response or better (39\% vs. $26 \% ; p<0.0001)$ and an improved PFS (HR $0.47 ; 95 \%$ CI $0.33-0.67 ; p<0.0001$ ) was observed. Currently, no OS benefit has been reported from the CASSIOPEIA trial. 
At least three other CD38 monoclonal antibodies are under investigation for MM treatment. Isatuximab (SAR650984) is a chimeric IgG1 CD38 monoclonal antibody targeting a different epitope of CD38 than daratumumab [50]. Single-agent isatuximab demonstrated a reasonable ORR of $40.9 \%$, with median PFS and OS of 4.6 and 18.7 months, respectively [51]. Isatuximab in combination with lenalidomide and dexamethasone demonstrated and ORR of $56 \%(29 / 52)$ [52]. The phase III ICARIA-MM study evaluated isatuximab, pomalidomide and dexamethasone versus Pd alone in 307 RRMM patients [53]. At a median follow-up of 11.6 months, median PFS was greater in the isatuximab, pomalidomide and dexamethasone arm (11.5 vs. 6.4 months; HR 0.596, 95\% CI 0.44-0.81; $p=0.001)$. In March 2020, the FDA approved isatuximab (SARCLISA) in combination with Pd for adult patients with multiple myeloma who have received at least two prior therapies, including lenalidomide and a proteasome inhibitor. Isatuximab is currently being evaluated in combination with $\mathrm{Vd}, \mathrm{Kd}, \mathrm{Rd}$ and RVd in newly diagnosed and RRMM patients in a number of clinical trials [54-56]. Additional anti-CD38 monoclonal antibodies (MOR202, TAK-079) have been examined in pre-clinical studies [57]. Phase 1/2 data exploring MOR202 and TAK-079 have recently been published, and further clinical evaluation is underway [58,59]. Overall, CD38 monoclonal antibodies have demonstrated reasonable but not spectacular single-agent efficacy in RRMM patients; however, their use in combination with established therapies appears to significantly improve response rates and survival. In newly diagnosed MM patients, CD38 monoclonal antibodies appear effective and, in the right combination, improve survival, particularly in those who are ineligible for upfront autologous bone marrow transplantation.

\subsubsection{CD138}

CD138 (syndecan-1) is a transmembrane protein receptor that is expressed on malignant PCs as well as epithelial cells and is used as primary diagnostic marker for MM [34,60]. Indatuximab ravtansine (BT062) is an antibody-drug conjugate (ADC) consisting of the anti-chimerised monoclonal antibody (nBT062) and the microtubule binding agent maytansinoid DM4 toxin. Indatuximab ravtansine specifically binds to CD138-expressing cells and, once internalised, DM4 is released to cause cell cycle arrest via tubulin binding followed by apoptosis [61,62]. Phase I/II data of the ADC as a single-dose or multi-dose regimen in RRMM demonstrated a disappointing ORR for this drug as a single agent of $6 \%$ and a short median time to progression (1.8 months) [63]. Similar to CD38 monoclonal antibodies, limited single-agent efficacy has led to indatuximab ravtansine being investigated in combination with standard myeloma regimens. Combinations with $\mathrm{Rd}$ or $\mathrm{Pd}$ in RRMM have demonstrated promising early results, with an ORR of $54 \%$ and $79 \%$ observed, respectively [64].

\subsubsection{B-Cell Maturation Antigen (BCMA)}

B-cell maturation antigen (BCMA; TNFRSF17) is a member of the tumour necrosis factor receptor superfamily and plays a significant role during plasma cell differentiation and survival via interaction with its ligands, BAFF and APRIL $[65,66]$. BCMA is selectively expressed by plasmablasts and differentiated PCs but not by B lymphocytes, haematopoietic stem cells and non-haematopoietic tissue [67]. Overexpression of BCMA in MM murine models resulted in the upregulation of genes associated with osteoclast activation, adhesion, angiogenesis/metastasis and immunosuppression [65]. Additionally, compared to healthy donors, elevated levels of serum BCMA (sBCMA) have been identified in patients with plasma cell dyscrasias, where the levels correlated with the plasma cell burden in bone marrow biopsies, clinical course and changes in paraprotein [68]. sBCMA levels above the median were predictive of a significantly shorter PFS and OS in MM patients. These data have highlighted BCMA as an attractive target in myeloma; however, studies have also demonstrated that normal plasma cells can survive BCMA suppression, thought mainly via a compensatory mechanism of upregulation of its co-family receptor TACI [69]. Suppression of BCMA in malignant plasma cells has shown variable effects [70,71]. Whilst 
targeting BCMA with monoclonal antibodies has shown some efficacy in killing myeloma cells in vitro, a range of alternate methods of targeting BCMA are in clinical trials and include ADCs, bi-specific T-cell engagers (BiTE) and chimeric antigen-receptor T-cell (CAR-T) conjugates [72].

Belantamab mafodotin (GSK2857916) is the first therapeutic anti-BCMA ADC consisting of a humanised IgG1 anti-BCMA antibody conjugated with the toxin monomethyl auristatin $\mathrm{F}$ (MMAF) [73]. Upon binding to BCMA on the cell surface, belantamab mafodotin is rapidly internalised, and the cytotoxic MMAF is released, resulting in apoptosis [74]. Preclinical data also demonstrates that macrophage-mediated phagocytosis of MM cells is induced by the agent [69]. The first in-human phase I (DREAMM-1) study evaluated belantamab mafodotin in RRMM patients, of which $89 \%$ were double refractory to PIs and IMiDs, and 37\% were refractory to daratumumab. A promising ORR of $60 \%$ was observed, with a median PFS of 12 months and a median duration of response of 14.3 months. Grade 1/2 corneal events were a frequent occurrence throughout the study, with the most common grade 3/4 events, thrombocytopenia and anaemia [75]. The follow-up phase II DREAMM-2 study examining different dosing regimens failed to replicate the response rates in DREAMM-1, with ORR of 32-34\%. The main difference in participants characteristics was that almost all patients in DREAMM-2 had been exposed and were refractory to daratumumab [76]. The mechanism by which CD38 monoclonal exposure and resistance appear to lead to loss of effectivity of belantamab remains unclear.

A number of clinical trials utilising belantamab mafodotin in combination with other anti-myeloma agents are currently active or recruiting. The DREAMM-6 study is an open-label phase I/II study evaluating the safety, tolerability and efficacy of belantamab mafodotin when administered in combination with $\mathrm{Rd}$ or $\mathrm{Vd}$ in patients with RRMM who have become refractory or relapsed after one or more prior treatment lines [77]. Preliminary results from DREAMM-6 demonstrate that belantamab mafodotin in combination with Vd results in an overall response rate of $78 \%$, with $50 \%$ of patients experiencing at least a very good partial response (VGPR). These results suggest that, like CD38 monoclonal antibodies, the combination of belantamab mafodotin with established therapies in myeloma can increase the response rates.

A second method of targeting BCMA is via BiTE antibodies which operate by forming an immunological synapse between a tumour antigen and a CD3+ T-cell, resulting in T cell binding to the tumour cell, activation and tumour lysis [78]. To date, at least eight BCMA BiTE antibodies are currently in clinical development, many of which are still recruiting in phase I dose escalation trials [79]. Recent phase I trials as single agents demonstrate that different BiTE antibodies have objective response rates between 70 and $83 \%$ at optimal dosing levels [80,81]. More data and longer follow-up are required, but the promising single-agent efficacy with acceptable toxicity profile has led to a number of proposals combining BCMA targeting BiTE antibodies in combination with standard therapies.

A third method of targeting BCMA has also been explored in MM and uses CAR-T cell therapy. CAR-T therapy involves the cultivation of T-cells harbouring a synthetic receptor directed against a tumour-associated antigen that is independent of the major histocompatibility complex [82]. CAR-T therapies directed against CD19 have shown promising success in refractory B-cell malignancies [83,84]. Over 20 different anti-BCMA CAR-T products have been developed and are undergoing clinical assessment. BCMA CAR-T cells have recently been discussed in a systematic review and meta-analysis, [85] with detailed review outside the scope of this article. In brief, this review assessed the safety and clinical efficacy of BCMA CAR-T therapy in $640 \mathrm{MM}$ patients and revealed a pooled ORR of $80.5 \%$, with a CR observed in $44.8 \%$ and a median PFS of 12.2 months. However, significant toxicity was observed, including cytokine release syndrome in $80.3 \%$ and neurotoxicity in $10.5 \%$ of the patients. Nevertheless, BCMA-targeted CAR-T therapy appears highly efficacious in advanced MM. A summary of recent studies presented at the American Society of Haematology Scientific Meeting in December 2020 can be seen in Table 1. Similar to the previously mentioned meta-analysis, these studies show very 
promising response rates and duration of response, albeit the numbers of patients treated remain small, with short duration of follow-up. We await with anticipation further later phase trials which are currently recruiting for BCMA CAR-T cells.

Table 1. CAR-T cell studies presented as oral presentations at the American Society of Haematology Scientific Meeting December 2020.

\begin{tabular}{|c|c|c|c|c|c|c|c|c|}
\hline Authors & Product & $\begin{array}{c}\text { Total } \\
\text { Num- } \\
\text { ber of } \\
\text { Pa- } \\
\text { tients } \\
*\end{array}$ & $\begin{array}{l}\text { ORR of } \\
\text { All } \\
\text { Patients }\end{array}$ & $\begin{array}{l}\text { Duration of } \\
\text { Response }\end{array}$ & $\underset{\text { Dose }}{\text { Optimal Cell }}$ & $\begin{array}{c}\text { Number of } \\
\text { Patients } \\
\text { with Opti- } \\
\text { mal } \\
\text { Dose }\end{array}$ & $\begin{array}{l}\text { ORR at } \\
\text { Optimal } \\
\text { Dose }\end{array}$ & $\begin{array}{l}\text { Median } \\
\text { Duration of } \\
\text { Follow Up }\end{array}$ \\
\hline $\begin{array}{l}\text { Mailankody } \\
\text { et al. [86] }\end{array}$ & $\begin{array}{l}\text { Allogeneic BCMA } \\
\text { CAR-T cells with } \\
\text { CD52 monoclonal } \\
\text { antibody }\end{array}$ & 27 & $\begin{array}{l}11 / 27 \\
(40 \%)\end{array}$ & Not reported & $3.2 \times 10^{8}$ & 10 & $6 / 10(60 \%)$ & 3.2 months \\
\hline $\begin{array}{c}\text { Alsina et al. } \\
\text { [87] }\end{array}$ & $\begin{array}{l}\text { Autologous BCMA } \\
\text { CAR-T cells culture } \\
\text { with PI3K inhitibor }\end{array}$ & 59 & $\begin{array}{l}40 / 59 \\
(68 \%)\end{array}$ & $\begin{array}{l}17 \text { months } \\
\text { (estimated) }\end{array}$ & $4.5 \times 10^{8}$ & 33 & $\begin{array}{l}24 / 33 \\
(73 \%)\end{array}$ & 5.8 months \\
\hline Lin et al. [88] & $\begin{array}{l}\text { Autologous BCMA } \\
\text { CAR-T cells }\end{array}$ & 62 & $\begin{array}{c}47 / 62 \\
(75.8 \%)\end{array}$ & 10.3 months & $8 \times 10^{8}$ & 3 & $3 / 3(100 \%)$ & 18.1 months \\
\hline $\begin{array}{l}\text { Hao et al. } \\
\text { [89] }\end{array}$ & $\begin{array}{c}\text { Autologous fully } \\
\text { humanised BCMA } \\
\text { CAR-T cells }\end{array}$ & 24 & $\begin{array}{c}21 / 24 \\
(87.5 \%)\end{array}$ & 21.8 months & $1.5 \times 10^{8}$ & 21 & $\begin{array}{l}\text { Not } \\
\text { reported }\end{array}$ & 17.7 months \\
\hline$\underset{[90]}{\text { Kumar et al. }}$ & $\begin{array}{l}\text { Autologous BCMA } \\
\text { CAR-T cells } \\
\text { Autologous BCMA }\end{array}$ & 18 & $\begin{array}{l}17 / 18 \\
(94 \%)\end{array}$ & Not reported & $2.5-3 \times 10^{8}$ & 6 & $\begin{array}{l}\text { Not } \\
\text { reported }\end{array}$ & 6 months \\
\hline $\begin{array}{l}\text { Costello et al. } \\
\text { [91] }\end{array}$ & $\begin{array}{l}\text { CAR-T cells } \\
\text { manufactured with } \\
\text { nanoplasmids }\end{array}$ & 30 & $\begin{array}{l}17 / 30 \\
(57 \%)\end{array}$ & Not reported & $8.47 \times 10^{8}$ & 4 & $3 / 4(75 \%)$ & $\begin{array}{l}\text { Not } \\
\text { reported }\end{array}$ \\
\hline $\begin{array}{l}\text { Madduri } \\
\text { et al. [92] }\end{array}$ & $\begin{array}{l}\text { Autologous BCMA } \\
\text { CAR-T cells }\end{array}$ & 97 & $\begin{array}{c}94 / 97 \\
(96.9 \%)\end{array}$ & Not reached & $0.5-1.0 \times 10^{6} / \mathrm{kg}$ & 97 & $\begin{array}{l}94 / 97 \\
(96.9 \%)\end{array}$ & 12.4 months \\
\hline $\begin{array}{c}\text { Jiang et al. } \\
\text { [93] }\end{array}$ & $\begin{array}{l}\text { Autologous } \\
\text { BCMA/CD19 dual } \\
\text { CAR-T cells }\end{array}$ & 16 & $\begin{array}{l}15 / 16 \\
(93.6 \%)\end{array}$ & Not reported & $3 \times 10^{5} / \mathrm{kg}$ & 6 & $6 / 6(100 \%)$ & 7.3 months \\
\hline An et al. [94] & $\begin{array}{c}\text { Second-generation } \\
\text { Autologous BCMA } \\
\text { CAR-T cells }\end{array}$ & 23 & $\begin{array}{c}22 / 23 \\
(95.7 \%)\end{array}$ & Not reached & $4.5-6 \times 10^{6} / \mathrm{kg}$ & 9 & $\begin{array}{c}8 / 9 \\
(88.9 \%)\end{array}$ & 6.2 months \\
\hline
\end{tabular}

ORR $=$ overall response rate, ${ }^{*}$ total number of patients refers to total number of evaluable patients, optimal cell dose was determined by the investigators.

\subsubsection{SLAMF7}

Signalling lymphocytic activation molecule (SLAM) family receptors are highly expressed in haematopoietic cells and serve an important role in the regulation of the normal immune system [95]. SLAMF7 is a cell surface glycoprotein receptor that is expressed on NK cells, CD8+ T cells, activated B-cells and dendritic cells, as well as normal and malignant PCs [96]. It has distinctive features not found in other members of the SLAM family that make it a compelling therapeutic target in myeloma. Additionally, increased expression of SLAMF7 is observed in MM cells independent of molecular profile, molecular subtype or the presence of cytogenetic abnormalities [96,97]. Its role in myelomagenesis is supported by SLAMF7 overexpression inducing increased MM cell adhesion to bone marrow stromal cells, cyclin D2-dependent proliferation and VEGF-induced bone marrow angiogenesis in preclinical models [98]. High levels of soluble SLAMF7 (sSLAMF7) have been correlated with more aggressive clinical characteristics and shorter PFS times when compared to sSLAMF7-negative MM patients. Furthermore, sSLAMF7 levels are undetectable or decreased following treatment, highlighting its role as a potential biomarker for MM therapy [99].

Elotuzumab is a humanised IgG1 monoclonal antibody that targets the extracellular domain of SLAMF7, with limited interaction with other members of the SLAM family. Elotuzumab induces selective lysis of myeloma cells via activation of NK cells. The Fab portion of elotuzumab binds SLAMF7 expressed on malignant PCs, while the Fc portion of the drug binds the activating Fc receptor, CD16, present on NK cells. This interaction triggers NK cell activation via recruitment of the adaptor protein EAT2 and the release of cytotoxic granules against the tagged tumour cells [100]. Due to the absence of EAT2 in MM 
cells, elotuzumab engagement does not result in activation of tumour cells. Additionally, elotuzumab reduces MM cell adhesion in the bone marrow microenvironment [97].

Elotuzumab as a single agent demonstrates a modest response, as shown in the initial phase I study in 35 RRMM patients, where 9 patients (26.5\%) obtained stable disease, and the remaining experienced progressive disease (PD) [101]. Phase I combination studies of elotuzumab with either $\mathrm{Vd}$ or $\mathrm{Rd}$ have demonstrated greater synergistic efficacy, with ORR of $48 \%$ and $82 \%$, respectively [102,103]. In the phase III ELOQUENT-2 study, elotuzumab was examined in combination with lenalidomide and dexamethasone (ERd versus $\mathrm{Rd}$ ) in RRMM having previously received 1-3 lines of prior therapy [104]. The ORR in the elotuzumab group was $79 \%$, while it was $66 \%$ in the control group $(p<0.001)$, with a median PFS of 19.4 versus 14.9 months in the elotuzumab group. The final overall survival results of ELOQUENT-2 demonstrated a statistically significant 8.7-month improvement in OS with ERd versus Rd (median 48.3 vs. 39.6 months, $p=0.0408$ ) [105]. This improvement in OS was greatest amongst subgroups generally associated with poorer outcomes, including patients with IMWG high-risk disease (median, 29.8 vs. 24.8 months), disease refractory to the last prior therapy (median, 40.4 vs. 25.9 months), ISS stage III disease (median, 21.7 vs. 14.0 months) and adverse cytogenetic abnormalities. The phase II ELOQUENT-3 examining elotuzumab in addition to pomalidomide and dexamethasone (EPd versus $\mathrm{Pd}$ ) demonstrated an ORR of $52 \%$ in the elotuzumab arm as compared with $26 \%$ in the control group. The median PFS was 10.3 months, versus 4.7 months in the elotuzumab group versus the control group [106]. Importantly, the addition of elotuzumab to lenalidomide or pomalidomide in the above studies was not associated with increased toxicity. The addition of elotuzumab to $\mathrm{Vd}$ in a phase II clinical trial showed a trend towards increased OS and PFS (median, 9.7 vs. 6.9 months, $p=0.09$ ) but did not reach statistical significance [107].

The evaluation of elotuzumab combinations in untreated, newly diagnosed MM patients has yielded underwhelming results. Data from the phase III ELOQUENT-1 study evaluating ERd versus Rd in newly diagnosed, previously untreated and transplantineligible patients have not shown a statistically significant improvement in PFS, as reported by Bristol-Myer-Squibbs. A full evaluation of the ELOQUENT-1 data will be presented at a future meeting. A second study, SWOG-1211, is a randomised phase II trial comparing RVd with or without elotuzumab in patients with untreated, high-risk multiple myeloma. No difference in median PFS was observed between RVd-elotuzumab and RVd (31.47 vs. 33.64 months) [108]. Overall, elotuzumab appears most effective in relapsed/refractory patients in combination with an established regimen containing IMiDs, where it has shown minimal toxicity and improved survival rates.

\subsection{Inhibitors of Nuclear Cytoplasmic Transport Receptors: Exportin 1}

Exportin 1 (XPO1; CRM1) is a ubiquitous nuclear-cytoplasmic transport receptor that serves as a carrier protein enhancing transportation from the nucleus to the cytoplasm. Dysregulation of XPO1 in cancer results in the export from the nucleus of tumour suppressor proteins that have a critical growth inhibitory and apoptotic role, in turn sequestrating them within the cytoplasm and promoting a pro-tumour state [109]. Furthermore, overexpression of XPO1 correlates with a poor prognosis or resistance to chemotherapy in a range of solid tumour sand haematological malignancies. Increased XPO1 expression correlates with disease progression in MM, lytic lesions, short survival and PI resistance [110,111].

Selinexor (KPT-330) is an orally bioavailable, selective inhibitor of XPO1-mediated nuclear export. The phase II (STORM) trial examined selinexor in conjunction with oral dexamethasone in a heavily pre-treated population refractory to over four lines of prior therapy. The ORR was $21 \%$, with a median PFS of 5 months and $65 \%$ of responding patients alive at 12 months [112]. Pre-clinical studies have demonstrated the synergistic antimyeloma activity of selinexor and proteasome inhibitors via suppression of NFkB signalling and the nuclear retention of tumour suppressor genes [113]. The phase II BOSTON study evaluating selinexor with low-dose bortezomib and dexamethasone (SVd) demonstrated an ORR of $63 \%$ with a median PFS of 9.0 months. Response rates were 
higher in proteasome inhibitor-non-refractory compared to proteasome inhibitor-refractory patients ( $84 \%$ vs. $43 \%$, respectively). The regimen was well tolerated, with most adverse events being grade $1 / 2$ [114]. Data from the follow-on phase III BOSTON study comparing the addition of selinexor to bortezomib and dexamethasone (SVd vs. Vd) were presented at the 2020 ASCO Virtual Program [115]. The study met its primary endpoint of a statistically significant increase in PFS with a median duration of 13.93 vs. 9.46 months in the SVd vs. Vd groups, respectively. This was true for all subgroups, including patients with $17 \mathrm{p}$ deletions and those previously treated with lenalidomide. Response rates were also significantly higher with SVd $(76.4 \%$ vs. $62.3 \%, p=0.0012)$. Median OS was not reached in the SVd group and was 25 months in the Vd arm. Peripheral neuropathy $\geq 2$ was less with SVd (21\% vs. $34 \%, p=0.0013)$, but the triple combination was associated with higher thrombocytopenia and more fatigue, nausea and treatment-related discontinuations. The STOMP trial is a multi-arm study evaluating three-drug regimens involving selinexor in combination with IMiDs, PIs and daratumumab. Early data from the arm utilizing selinexor and weekly carfilzomib plus dexamethasone in carfilzomib-naïve patients with a median four lines of prior therapy yielded an ORR of $72 \%$. With a median follow-up period of 4.7 (1.8-16.3) months, the median PFS has not been reached [116].

The combination of selinexor, pomalidomide and dexamethasone (SPd) demonstrated promising results, with an ORR of $58 \%$ in lenalidomide-treated or refractory and pomalidomide-naïve MM patients compared to $31 \%$ ORR with Pd in a similar population, as previously published [117]. A median PFS of 12.12 months was observed in the SPd arm in a population with a median four lines of prior therapy. All treatment-associated adverse events were expected and manageable with appropriate supportive care (e.g., G-CSF). Although the ORR is similar to that of previously published trials with pomalidomidebased triplet therapy, the ability to provide an oral triplet regimen is an attractive and advantageous option. Overall, early studies of selinexor suggest it is an efficacious therapy and shows promising results in combinations. Its novel method of action and parenteral mode of delivery makes it an encouraging addition to myeloma therapy.

\subsection{BCL-2 Family Proteins}

BCL-2 and its family members function as critical regulators of apoptosis and have been shown to play critical roles in myeloma survival [118-121]. Venetoclax (ABT-199) is a selective, orally bioavailable BCL-2 inhibitor with an expanding role in the treatment of both lymphoid and myeloid malignancies [122]. A subset of MM patients with $t(11 ; 14)$ translocations demonstrate a high dependency on BCL-2, and deeper, prolonged responses are observed in this subgroup. In a phase I study of venetoclax monotherapy in 66 patients with RRMM, the ORR was $21 \%(14 / 55)$, and $15 \%$ of the patients achieved a VGPR or better [123]. The majority of responses $(12 / 14[86 \%])$ were reported in patients within the $t(11 ; 14)$ subgroup. Within this group, the ORR was $40 \%$, with $26 \%$ of the patients achieving a VGPR or better. Further clinical evaluation in $\mathrm{t}(11 ; 14)$-positive RRMM patients demonstrated an ORR of $46 \%$, and >VGPR was observed in $26 \%$ of the patients [124]. The nine-month estimates for PFS and OS were $57 \%$ and $71 \%$, respectively. Consequently, this combination is being investigated in the ongoing phase III CANOVA trial in $\mathrm{t}(11 ; 14)$ positive RRMM [125].

Venetoclax in combination with other agents has also shown efficacy in $t(11 ; 14)$ negative patients. Upregulation of MCL-1 confers venetoclax resistance, which is abrogated by the addition of bortezomib in pre-clinical myeloma models [126]. The phase III BELLINI study assesses the efficacy of venetoclax or placebo in combination with Vd in 291 patients with RRMM [127]. With a median follow-up of 18.7 months, median PFS was greater with venetoclax (22.4 versus 11.5 months; $p=0.010$ ). Median OS was not reached in either group. Increased mortality was observed in the venetoclax group, predominantly due to increased rates of infection. The unexpected finding of increased mortality in the venetoclax group has complicated the use of venetoclax in combination with other therapies in myeloma; more in-depth analysis and further measures to minimise infection risk are required in 
the future. Given these findings, the role of BCL-2 inhibition remains unclear within the myeloma field.

\subsection{HDAC Inhibitors}

HDACs are critical epigenetic regulators of gene expression that function through the modification of histones. Panobinostat, a pan-HDAC inhibitor, has been approved by the FDA as a third-line treatment for RRMM patients previously treated with PI and IMiD. Panobinostat in conjunction with intravenous bortezomib and dexamethasone was examined in a phase III clinical trial (PANORAMA-1) and demonstrated efficacy in RRMM, with an improvement in median PFS and OS of four months [128]. However, serious adverse events were reported in $60 \%$ of patients in the panobinostat group compared to $42 \%$ in the placebo group. PANORAMA-3, a phase II study examining three different dosing regimens of panobinostat with subcutaneous (SC) bortezomib and dexamethasone, has demonstrated a more favourable safety profile, suggesting that $\mathrm{SC}$ bortezomib improves the tolerability of the regimen [129]. The greatest ORR was observed in the three-time weekly group $(62.2 \%)$, at the expense of increased adverse events. Increased interest has been aimed at more selective HDAC inhibitors due to the side effects observed that often lead to treatment discontinuation. The newer selective inhibitor of HDAC6, ricolinostat (ACY-1215), appears to be one of the more promising agents in RRMM. The single agent ricolinostat in combination with bortezomib and dexamethasone in phase I/II trials showed an ORR of $37 \%$ [130]. In a multicentre phase Ib study in combination with lenalidomide and dexamethasone, the overall response rate was 55\% [131]. Both studies reported favourable tolerability and limited related adverse events. Figure 1 shows the therapeutic targets in myeloma.

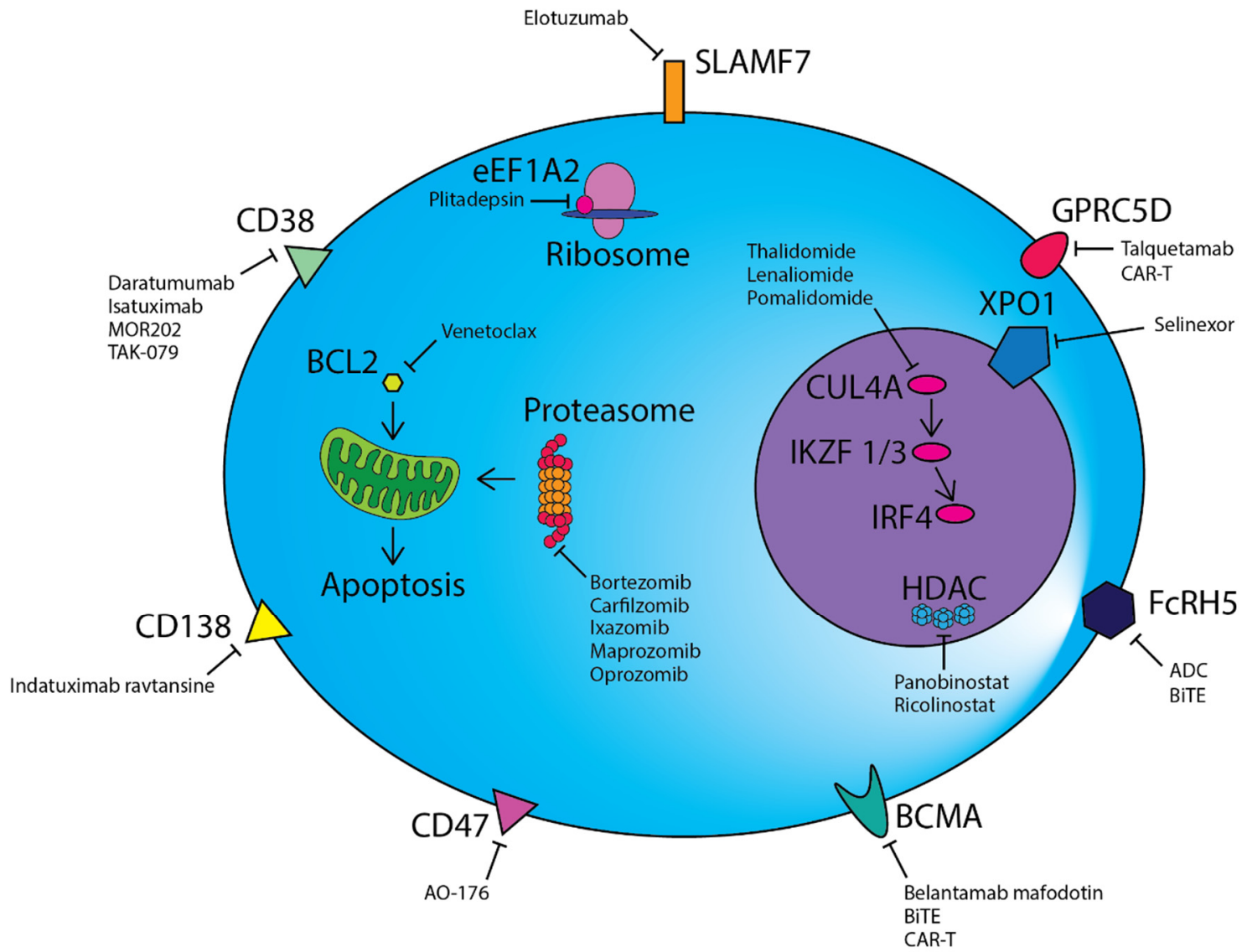

Figure 1. Therapeutic modalities in multiple myeloma. 
CD38, CD47, CD138, SLAMF7, GPRC5D, FCRH5 and BCMA are highly expressed on the surface of malignant plasma cells and are targeted by a range of different monoclonal antibodies or antibody-drug conjugates. Chimeric antigen receptor T-cell (CAR-T) and bispecific T-cell engager (BiTE) cellular therapies directed against BCMA, GPRC5D and FcRH5 are also a novel therapeutic avenue. Proteasome inhibitors prevent the degradation of misfolded proteins via the proteasome, resulting in eventual cell death due to the unfolded protein response. BCL2 inhibitors such as venetoclax induce mitochondrial outer membrane permeabilization, culminating in apoptosis. IMiDs alter the target specificity of Cereblon (CRBN) as part of an E3 ubiquitin ligase complex and lead to the degradation of Ikaros (IKZF1) and Aiolos (IKZF3), which consequently results in a reduction in IRF4, a key mediator of the oncogene MYC. Plitadepsin binds to eEF1A2 in the ribosome and abrogates its pro-oncogenic moonlighting effects. Additional therapies directed against targets within the nucleus include the nuclear transport protein XPO-1 and epigenetic regulators such as histone deacetylases (HDACs).

\subsection{Plitadepsin}

Plitadepsin (Aplidin ${ }^{\circledR}$ ) is a synthetically produced cyclic depsipeptide that exerts its anticancer effects by binding to eukaryotic Elongation Factor 1A2 (eEF1A2), a protein which is overexpressed in a range of tumours, including MM [132]. The predominant function of eEF1A2 involves the delivery of aminoacyl-tRNAs to the ribosome, but it also demonstrates pro-oncogenic moonlighting effects including inhibition of apoptosis, protein degradation by the proteasome, heat shock response and regulation of oxidative stress [132,133]. Plitadepsin also binds to the Rac1 GTPase, resulting in the sustained activation of c-Jun-N-terminal kinase (JNK) and p38 mitogen-activated protein kinases (p38/MAPK) signalling pathways, culminating in caspase-dependent apoptosis [134].

Plitadepsin was administered intravenously alone or in combination with dexamethasone in a phase II study evaluating its clinical and safety profile in RRMM [135]. In 47 of 51 patients evaluable for efficacy, the ORR was $13 \%$ with plitadepsin alone, while it was and $22 \%$ in the cohort of patients also receiving dexamethasone $(n=19)$. Plitadepsin was well tolerated both alone or in combination, with anaemia (29\%) and thrombocytopenia (18\%) being the most frequent grade $3 / 4$ haematologic toxicities. Non-haematological adverse events included fatigue (16\%), muscular toxicity $(6 \%)$, transient AST / ALT elevation $(27 \%)$ and CK increases (23\%). Following on from these results, the randomized phase III ADMYRE trial evaluated plitadepsin plus dexamethasone alone in RRMM after at least three prior therapeutic regimens [136]. Median PFS was 2.6 months in the plitadepsin group and 1.7 months in the control arm $(p=0.0054)$, with a median OS of 11.6 versus 8.6 months $(p=0.1261)$. OS improvement favouring plitadepsin was observed when discounting the crossover effect (37 patients crossed over from the control group) $(p=0.0015)$. The most common grade $3 / 4$ toxicities were fatigue $(10.8 \%)$, myalgia $(5.4 \%)$ and nausea $(3.6 \%)$ in the plitadepsin arm.

A phase I trial combining plitadepsin with Vd in 18 evaluable patients with RRMM produced an ORR of $56 \%$, with $33 \%$ of the patients achieving at least a VGPR [137]. A median PFS of 8.3 months was observed. No dose-limiting toxicities were observed, and grade $3 / 4$ haematological toxicities included anaemia $(25 \%)$, neutropenia $(25 \%)$ and thrombocytopenia (60\%). Non-haematological toxicities were mild.

Although single-agent efficacy is underwhelming, the safety profile of plitadepsin does not appear to present the same toxicities associated with other anti-myeloma agents. Additionally, the novel mechanism of action may prove that plitadepsin in combination with other anti-myeloma agents may be an alternative option for RRMM.

\subsection{Other Novel Targeted Therapies}

CD47 is an immune checkpoint that is overexpressed in a number of haematological and solid tumours. Macrophages express the checkpoint receptor, signal regulatory protein $\alpha(\mathrm{SIRP} \alpha / \mathrm{CD} 172 \mathrm{a})$, which recognizes $\mathrm{CD} 47$ on target cells. Interactions between CD47 and 
SIRP $\alpha$ generate a "don't eat me" signal by initiating a signalling cascade that eventuates with the inhibition of macrophage phagocytic activity [138]. CD47 expression is markedly higher in MM cells compared to other constituents of the bone marrow milieu, and its levels appear to correlate with disease progression from normal PCs to MM [139]. In vitro inhibition of CD47 using an anti-CD47 antibody (Vx1000R) induced phagocytosis as early as $4 \mathrm{~h}$ after treatment, which continued to increase over $24 \mathrm{~h} \mathrm{[139].} \mathrm{AO-176} \mathrm{is} \mathrm{a} \mathrm{novel}$ anti-CD47 antibody that exerts substantial single-agent in vivo anti-tumour activity in MM xenograft models [140]. A phase I study of AO-176 in MM is currently recruiting (NCT04445701). Overall, these results highlight targeting CD47 as a novel and promising strategy in the treatment of MM. However, we cautiously await further validation from clinical trials, given the previous experience of checkpoint blockade of PD-1 in MM, with pre-clinical data not translating to clinical efficacy and the appearance of significant adverse events [141,142].

The orphan G protein-coupled receptor, class C group 5 member D (GPRC5D) is expressed on malignant PCs, whereas its expression in normal tissue is limited to the hair follicle [143]. In preclinical models, GPRC5D-targeted CAR-T therapy demonstrated in vivo activity in MM xenograft mice, with comparable tumour regression compared to BCMAtargeted CAR-T therapy [143]. Phase I evaluation of a first-in-class bispecific antibody that binds to GPRC5D and CD3 (talquetamab) in RRMM was recently presented at the ASH 2020 meeting [144]. ORR for IV doses was 78\% (14/18), whilst SC administration demonstrated an ORR of $67 \%(8 / 12)$. Responses were durable, and the median was not reached in $36 / 46$ patients. Four patients demonstrated a response lasting over 15 months, with the current longest response being over 23 months. The most common grade 3/4 AEs were lymphopenia (37\%), anaemia (27\%) and neutropenia $(25 \%)$. Cytokine release syndrome (CRS) was predominantly grade $1 / 2$, except for five patients with grade CRS who received IV dosing. A maximum tolerated dose has not been defined. The encouraging pre-clinical and clinical activity of GPRC5D CAR-T or BiTE therapies support ongoing monotherapy development and combination approaches.

Fc receptor-homolog 5 (FcRH5; also known as FcRL5, IFGP5, CD307 and IRTA2) is a cell surface antigen of unknown function whose expression is restricted to mature $B$ cells, with greater expression on malignant PCs $[145,146]$. DFRF4539A is an ADC that contains a humanized IgG1 anti-human FcRH5 monoclonal antibody (MFRF3266A) and a potent anti-mitotic agent, monomethyl auristatin E. A phase I study of DFRF4539A in RRMM showed limited clinical activity with 34 of 37 patients demonstrating SD or PD [147]. Consequently, further investigation of DFRF4539A has ceased. An FcRH5 BiTE antibody (BFCR4350A) has demonstrated promising results in primates, with complete depletion of BM PCs without severe or prolonged cytokine release [148]. A phase I study assessing BFCR4350A is currently recruiting (NCT03275103).

\section{Conclusions}

Over the last decade, a plethora of novel agents have become available for the treatment of myeloma (Figure 1). With the potential exception of CAR-T cells, they all have demonstrated some, but limited, efficacy as single agents in RRMM. As a result, many have been trialled and shown to be efficacious either when combined with established myeloma therapies, in specific subgroups of patients, or in earlier stages of the disease. Excitingly, many of these new agents have unique modes of action, and most have acceptable toxicity profiles, with relative specificity for targeting myeloma cells. Despite the therapeutic options these agents provide, there are a number of questions which remain unanswered. Firstly, determining which of these agents, in conjunction with established therapies, will be the ideal treatment for myeloma patients by balancing optimal efficacy with minimal toxicity; secondly, in which order should these therapies be used in patients with myeloma to achieve the best responses and survival outcomes; lastly, if the potential for cure for myeloma lies within the combination of therapies discussed within this article. Answering 
these three major questions, as well as the ongoing discovery of new therapies, are the major challenges of the future for myeloma clinicians, researchers and patients alike.

Author Contributions: Writing-original draft preparation, C.C.-Y.L., M.S.Y.L.; writing-review and editing, C.C.-Y.L., M.S.Y.L.; All authors have read and agreed to the published version of the manuscript.

Funding: This research received no external funding.

Institutional Review Board Statement: Not applicable.

Informed Consent Statement: Not applicable.

Data Availability Statement: Not applicable.

Conflicts of Interest: The authors declare no conflict of interest.

\section{References}

1. Swerdlow, S.H.; Campo, E.; Harris, N.L.; Jaffe, E.S.; Pileri, S.A.; Stein, H.; THiele, J.; Arber, D.A.; Hasserjian, R.P.; Le Beau, M.M.; et al. WHO Classification of Tumours of Haematopoietic and Lymphoid Tissues, 4th ed.; International Agency for Research on Cancer (IARC): Lyon, France, 2017.

2. Hallek, M.; Bergsagel, P.L.; Anderson, K.C. Multiple myeloma: Increasing evidence for a multistep transformation process. Blood 1998, 91, 3-21. [CrossRef] [PubMed]

3. Agarwal, A.; Ghobrial, I.M. Monoclonal gammopathy of undetermined significance and smoldering multiple myeloma: A review of the current understanding of epidemiology, biology, risk stratification, and management of myeloma precursor disease. Clin. Cancer Res. 2013, 19, 985-994. [CrossRef]

4. Fonseca, R.; Bailey, R.J.; Ahmann, G.J.; Rajkumar, S.V.; Hoyer, J.D.; Lust, J.A.; Kyle, R.A.; Gertz, M.A.; Greipp, P.R.; Dewald, G.W. Genomic abnormalities in monoclonal gammopathy of undetermined significance. Blood 2002, 100, 1417-1424. [CrossRef] [PubMed]

5. Sawyer, J.R. The prognostic significance of cytogenetics and molecular profiling in multiple myeloma. Cancer Genet. 2011, 204, 3-12. [CrossRef] [PubMed]

6. Kuehl, W.M.; Bergsagel, P.L. Multiple myeloma: Evolving genetic events and host interactions. Nat. Rev. Cancer 2002, 2, 175-187. [CrossRef] [PubMed]

7. Keats, J.J.; Fonseca, R.; Chesi, M.; Schop, R.; Baker, A.; Chng, W.J.; Van Wier, S.; Tiedemann, R.; Shi, C.X.; Sebag, M.; et al. Promiscuous mutations activate the noncanonical NF-kappaB pathway in multiple myeloma. Cancer Cell 2007, 12, 131-144. [CrossRef]

8. Annunziata, C.M.; Davis, R.E.; Demchenko, Y.; Bellamy, W.; Gabrea, A.; Zhan, F.; Lenz, G.; Hanamura, I.; Wright, G.; Xiao, W.; et al. Frequent engagement of the classical and alternative NF-kappaB pathways by diverse genetic abnormalities in multiple myeloma. Cancer Cell 2007, 12, 115-130. [CrossRef]

9. Liu, P.; Leong, T.; Quam, L.; Billadeau, D.; Kay, N.E.; Greipp, P.; Kyle, R.A.; Oken, M.M.; Van Ness, B. Activating mutations of Nand K-ras in multiple myeloma show different clinical associations: Analysis of the Eastern Cooperative Oncology Group Phase III Trial. Blood 1996, 88, 2699-2706. [CrossRef]

10. Schübeler, D. Function and information content of DNA methylation. Nature 2015, 517, 321-326. [CrossRef]

11. Walker, B.A.; Mavrommatis, K.; Wardell, C.P.; Ashby, T.C.; Bauer, M.; Davies, F.E.; Rosenthal, A.; Wang, H.; Qu, P.; Hoering, A.; et al. Identification of novel mutational drivers reveals oncogene dependencies in multiple myeloma. Blood 2018, 132, 587-597. [CrossRef] [PubMed]

12. Pawlyn, C.; Bright, M.D.; Buros, A.F.; Stein, C.K.; Walters, Z.; Aronson, L.I.; Mirabella, F.; Jones, J.R.; Kaiser, M.F.; Walker, B.A.; et al. Overexpression of EZH2 in multiple myeloma is associated with poor prognosis and dysregulation of cell cycle control. Blood Cancer J. 2017, 7, e549. [CrossRef]

13. De Smedt, E.; Lui, H.; Maes, K.; De Veirman, K.; Menu, E.; Vanderkerken, K.; De Bruyne, E. The Epigenome in Multiple Myeloma: Impact on Tumor Cell Plasticity and Drug Response. Front. Oncol. 2018, 8. [CrossRef]

14. Kawano, M.; Hirano, T.; Matsuda, T.; Taga, T.; Horii, Y.; Iwato, K.; Asaoku, H.; Tang, B.; Tanabe, O.; Tanaka, H.; et al. Autocrine generation and requirement of BSF-2/IL-6 for human multiple myelomas. Nature 1988, 332, 83-85. [CrossRef] [PubMed]

15. Manier, S.; Sacco, A.; Leleu, X.; Ghobrial, I.M.; Roccaro, A.M. Bone marrow microenvironment in multiple myeloma progression. J. Biomed. Biotechnol. 2012, 2012, 157496. [CrossRef] [PubMed]

16. Bianchi, G.; Munshi, N.C. Pathogenesis beyond the cancer clone(s) in multiple myeloma. Blood 2015, 125, 3049-3058. [CrossRef] [PubMed]

17. van Beurden-Tan, C.H.Y.; Franken, M.G.; Blommestein, H.M.; Uyl-de Groot, C.A.; Sonneveld, P. Systematic Literature Review and Network Meta-Analysis of Treatment Outcomes in Relapsed and/or Refractory Multiple Myeloma. J. Clin. Oncol. 2017, 35, 1312-1319. [CrossRef]

18. Obeng, E.A.; Carlson, L.M.; Gutman, D.M.; Harrington, W.J., Jr.; Lee, K.P.; Boise, L.H. Proteasome inhibitors induce a terminal unfolded protein response in multiple myeloma cells. Blood 2006, 107, 4907-4916. [CrossRef] [PubMed] 
19. Adams, J. The proteasome: A suitable antineoplastic target. Nat. Rev. Cancer 2004, 4, 349-360. [CrossRef]

20. Krönke, J.; Udeshi, N.D.; Narla, A.; Grauman, P.; Hurst, S.N.; McConkey, M.; Svinkina, T.; Heckl, D.; Comer, E.; Li, X.; et al. Lenalidomide causes selective degradation of IKZF1 and IKZF3 in multiple myeloma cells. Science 2014, 343, 301-305. [CrossRef]

21. Lu, G.; Middleton, R.E.; Sun, H.; Naniong, M.; Ott, C.J.; Mitsiades, C.S.; Wong, K.K.; Bradner, J.E.; Kaelin, W.G., Jr. The myeloma drug lenalidomide promotes the cereblon-dependent destruction of Ikaros proteins. Science 2014, 343, 305-309. [CrossRef]

22. Shaffer, A.L.; Emre, N.C.; Lamy, L.; Ngo, V.N.; Wright, G.; Xiao, W.; Powell, J.; Dave, S.; Yu, X.; Zhao, H.; et al. IRF4 addiction in multiple myeloma. Nature 2008, 454, 226-231. [CrossRef]

23. Moreau, P.; Attal, M.; Facon, T. Frontline therapy of multiple myeloma. Blood 2015, 125, 3076-3084. [CrossRef]

24. McCarthy, P.L.; Owzar, K.; Hofmeister, C.C.; Hurd, D.D.; Hassoun, H.; Richardson, P.G.; Giralt, S.; Stadtmauer, E.A.; Weisdorf, D.J.; Vij, R.; et al. Lenalidomide after stem-cell transplantation for multiple myeloma. N. Engl. J. Med. 2012, 366, 1770-1781. [CrossRef]

25. Palumbo, A.; Cavallo, F.; Gay, F.; Di Raimondo, F.; Ben Yehuda, D.; Petrucci, M.T.; Pezzatti, S.; Caravita, T.; Cerrato, C.; Ribakovsky, E.; et al. Autologous Transplantation and Maintenance Therapy in Multiple Myeloma. N. Engl. J. Med. 2014, 371, 895-905. [CrossRef] [PubMed]

26. Zhang, S.; Kulkarni, A.A.; Xu, B.; Chu, H.; Kourelis, T.; Go, R.S.; Wang, M.L.; Bachanova, V.; Wang, Y. Bortezomib-based consolidation or maintenance therapy for multiple myeloma: A meta-analysis. Blood Cancer J. 2020, 10, 33. [CrossRef]

27. Siegel, D.S.; Dimopoulos, M.A.; Ludwig, H.; Facon, T.; Goldschmidt, H.; Jakubowiak, A.; San-Miguel, J.; Obreja, M.; Blaedel, J.; Stewart, A.K. Improvement in Overall Survival With Carfilzomib, Lenalidomide, and Dexamethasone in Patients With Relapsed or Refractory Multiple Myeloma. J. Clin. Oncol. 2018, 36, 728-734. [CrossRef]

28. Dimopoulos, M.A.; Goldschmidt, H.; Niesvizky, R.; Joshua, D.; Chng, W.-J.; Oriol, A.; Orlowski, R.Z.; Ludwig, H.; Facon, T.; Hajek, R.; et al. Carfilzomib or bortezomib in relapsed or refractory multiple myeloma (ENDEAVOR): An interim overall survival analysis of an open-label, randomised, phase 3 trial. Lancet Oncol. 2017, 18, 1327-1337. [CrossRef]

29. Dimopoulos, M.A.; Leleu, X.; Palumbo, A.; Moreau, P.; Delforge, M.; Cavo, M.; Ludwig, H.; Morgan, G.J.; Davies, F.E.; Sonneveld, P.; et al. Expert panel consensus statement on the optimal use of pomalidomide in relapsed and refractory multiple myeloma. Leukemia 2014, 28, 1573-1585. [CrossRef] [PubMed]

30. Moreau, P.; Masszi, T.; Grzasko, N.; Bahlis, N.J.; Hansson, M.; Pour, L.; Sandhu, I.; Ganly, P.; Baker, B.W.; Jackson, S.R.; et al. Oral Ixazomib, Lenalidomide, and Dexamethasone for Multiple Myeloma. N. Engl. J. Med. 2016, 374, 1621-1634. [CrossRef]

31. Dou, Q.P.; Zonder, J.A. Overview of proteasome inhibitor-based anti-cancer therapies: Perspective on bortezomib and second generation proteasome inhibitors versus future generation inhibitors of ubiquitin-proteasome system. Curr. Cancer Drug Targets 2014, 14, 517-536. [CrossRef]

32. Mehta, K.; Shahid, U.; Malavasi, F. Human CD38, a cell-surface protein with multiple functions. FASEB J. 1996, 10, $1408-1417$. [CrossRef] [PubMed]

33. Deaglio, S.; Mehta, K.; Malavasi, F. Human CD38: A (r)evolutionary story of enzymes and receptors. Leuk Res. 2001, 25, 1-12. [CrossRef]

34. Lin, P.; Owens, R.; Tricot, G.; Wilson, C.S. Flow cytometric immunophenotypic analysis of 306 cases of multiple myeloma. Am. J. Clin. Pathol. 2004, 121, 482-488. [CrossRef]

35. de Weers, M.; Tai, Y.T.; van der Veer, M.S.; Bakker, J.M.; Vink, T.; Jacobs, D.C.; Oomen, L.A.; Peipp, M.; Valerius, T.; Slootstra, J.W.; et al. Daratumumab, a novel therapeutic human CD38 monoclonal antibody, induces killing of multiple myeloma and other hematological tumors. J. Immunol. 2011, 186, 1840-1848. [CrossRef] [PubMed]

36. Overdijk, M.B.; Verploegen, S.; Bögels, M.; van Egmond, M.; Lammerts van Bueren, J.J.; Mutis, T.; Groen, R.W.; Breij, E.; Martens, A.C.; Bleeker, W.K.; et al. Antibody-mediated phagocytosis contributes to the anti-tumor activity of the therapeutic antibody daratumumab in lymphoma and multiple myeloma. MAbs 2015, 7, 311-321. [CrossRef]

37. Lokhorst, H.M.; Plesner, T.; Laubach, J.P.; Nahi, H.; Gimsing, P.; Hansson, M.; Minnema, M.C.; Lassen, U.; Krejcik, J.; Palumbo, A.; et al. Targeting CD38 with Daratumumab Monotherapy in Multiple Myeloma. N. Engl. J. Med. 2015, 373, $1207-1219$. [CrossRef]

38. Lonial, S.; Weiss, B.M.; Usmani, S.Z.; Singhal, S.; Chari, A.; Bahlis, N.J.; Belch, A.; Krishnan, A.; Vescio, R.A.; Mateos, M.V.; et al. Daratumumab monotherapy in patients with treatment-refractory multiple myeloma (SIRIUS): An open-label, randomised, phase 2 trial. Lancet 2016, 387, 1551-1560. [CrossRef]

39. Usmani, S.Z.; Weiss, B.M.; Plesner, T.; Bahlis, N.J.; Belch, A.; Lonial, S.; Lokhorst, H.M.; Voorhees, P.M.; Richardson, P.G.; Chari, A.; et al. Clinical efficacy of daratumumab monotherapy in patients with heavily pretreated relapsed or refractory multiple myeloma. Blood 2016, 128, 37-44. [CrossRef] [PubMed]

40. Palumbo, A.; Chanan-Khan, A.; Weisel, K.; Nooka, A.K.; Masszi, T.; Beksac, M.; Spicka, I.; Hungria, V.; Munder, M.; Mateos, M.V.; et al. Daratumumab, Bortezomib, and Dexamethasone for Multiple Myeloma. N. Engl. J. Med. 2016, 375, 754-766. [CrossRef]

41. Weisel, K.; Spencer, A.; Lentzsch, S.; Avet-Loiseau, H.; Mark, T.M.; Spicka, I.; Masszi, T.; Lauri, B.; Levin, M.-D.; Bosi, A.; et al. Daratumumab, bortezomib, and dexamethasone in relapsed or refractory multiple myeloma: Subgroup analysis of CASTOR based on cytogenetic risk. J. Hematol. Oncol. 2020, 13, 115. [CrossRef] 
42. Dimopoulos, M.; Quach, H.; Mateos, M.V.; Landgren, O.; Leleu, X.; Siegel, D.; Weisel, K.; Yang, H.; Klippel, Z.; Zahlten-Kumeli, A.; et al. Carfilzomib, dexamethasone, and daratumumab versus carfilzomib and dexamethasone for patients with relapsed or refractory multiple myeloma (CANDOR): Results from a randomised, multicentre, open-label, phase 3 study. Lancet 2020, 396, 186-197. [CrossRef]

43. Chari, A.; Martinez-Lopez, J.; Mateos, M.V.; Bladé, J.; Benboubker, L.; Oriol, A.; Arnulf, B.; Rodriguez-Otero, P.; Pineiro, L.; Jakubowiak, A.; et al. Daratumumab plus carfilzomib and dexamethasone in patients with relapsed or refractory multiple myeloma. Blood 2019, 134, 421-431. [CrossRef] [PubMed]

44. Bahlis, N.J.; Dimopoulos, M.A.; White, D.J.; Benboubker, L.; Cook, G.; Leiba, M.; Ho, P.J.; Kim, K.; Takezako, N.; Moreau, P.; et al. Daratumumab plus lenalidomide and dexamethasone in relapsed/refractory multiple myeloma: Extended follow-up of POLLUX, a randomized, open-label, phase 3 study. Leukemia 2020, 34, 1875-1884. [CrossRef] [PubMed]

45. Siegel, D.S.; Schiller, G.J.; Samaras, C.; Sebag, M.; Berdeja, J.; Ganguly, S.; Matous, J.; Song, K.; Seet, C.S.; Talamo, G.; et al. Pomalidomide, dexamethasone, and daratumumab in relapsed refractory multiple myeloma after lenalidomide treatment. Leukemia 2020, 34, 3286-3297. [CrossRef] [PubMed]

46. Dimopoulos, M.A.; Terpos, E.; Boccadoro, M.; Delimpasi, S.; Beksac, M.; Katodritou, E.; Moreau, P.; Baldini, L.; Symeonidis, A.; Bila, J.; et al. Apollo: Phase 3 Randomized Study of Subcutaneous Daratumumab Plus Pomalidomide and Dexamethasone (D-Pd) Versus Pomalidomide and Dexamethasone (Pd) Alone in Patients (Pts) with Relapsed/Refractory Multiple Myeloma (RRMM). Blood 2020, 136, 5-6. [CrossRef]

47. Fedele, P.L.; Willis, S.N.; Liao, Y.; Low, M.S.; Rautela, J.; Segal, D.H.; Gong, J.N.; Huntington, N.D.; Shi, W.; Huang, D.C.S.; et al. IMiDs prime myeloma cells for daratumumab-mediated cytotoxicity through loss of Ikaros and Aiolos. Blood 2018, 132, $2166-2178$. [CrossRef]

48. Mateos, M.V.; Cavo, M.; Blade, J.; Dimopoulos, M.A.; Suzuki, K.; Jakubowiak, A.; Knop, S.; Doyen, C.; Lucio, P.; Nagy, Z.; et al. Overall survival with daratumumab, bortezomib, melphalan, and prednisone in newly diagnosed multiple myeloma (ALCYONE): A randomised, open-label, phase 3 trial. Lancet 2020, 395, 132-141. [CrossRef]

49. Moreau, P.; Attal, M.; Hulin, C.; Arnulf, B.; Belhadj, K.; Benboubker, L.; Béné, M.C.; Broijl, A.; Caillon, H.; Caillot, D.; et al. Bortezomib, thalidomide, and dexamethasone with or without daratumumab before and after autologous stem-cell transplantation for newly diagnosed multiple myeloma (CASSIOPEIA): A randomised, open-label, phase 3 study. Lancet 2019, 394, 29-38. [CrossRef]

50. Deckert, J.; Wetzel, M.C.; Bartle, L.M.; Skaletskaya, A.; Goldmacher, V.S.; Vallée, F.; Zhou-Liu, Q.; Ferrari, P.; Pouzieux, S.; Lahoute, C.; et al. SAR650984, a novel humanized CD38-targeting antibody, demonstrates potent antitumor activity in models of multiple myeloma and other CD38+ hematologic malignancies. Clin. Cancer Res. 2014, 20, 4574-4583. [CrossRef]

51. Mikhael, J.; Richter, J.; Vij, R.; Cole, C.; Zonder, J.; Kaufman, J.L.; Bensinger, W.; Dimopoulos, M.; Lendvai, N.; Hari, P.; et al. A dose-finding Phase 2 study of single agent isatuximab (anti-CD38 mAb) in relapsed/refractory multiple myeloma. Leukemia 2020, 34, 3298-3309. [CrossRef]

52. Martin, T.; Baz, R.; Benson, D.M.; Lendvai, N.; Wolf, J.; Munster, P.; Lesokhin, A.M.; Wack, C.; Charpentier, E.; Campana, F.; et al. A phase $1 \mathrm{~b}$ study of isatuximab plus lenalidomide and dexamethasone for relapsed/refractory multiple myeloma. Blood 2017, 129, 3294-3303. [CrossRef] [PubMed]

53. Attal, M.; Richardson, P.G.; Rajkumar, S.V.; San-Miguel, J.; Beksac, M.; Spicka, I.; Leleu, X.; Schjesvold, F.; Moreau, P.; Dimopoulos, M.A.; et al. Isatuximab plus pomalidomide and low-dose dexamethasone versus pomalidomide and low-dose dexamethasone in patients with relapsed and refractory multiple myeloma (ICARIA-MM): A randomised, multicentre, open-label, phase 3 study. Lancet 2019, 394, 2096-2107. [CrossRef]

54. Moreau, P.; Dimopoulos, M.A.; Yong, K.; Mikhael, J.; Risse, M.L.; Asset, G.; Martin, T. Isatuximab plus carfilzomib/dexamethasone versus carfilzomib/dexamethasone in patients with relapsed/refractory multiple myeloma: IKEMA Phase III study design. Future Oncol. 2020, 16, 4347-4358. [CrossRef] [PubMed]

55. Orlowski, R.; Goldschmidt, H.; Cavo, M.; Martin, T.; Paux, G.; Oprea, C.; Facon, T. Phase III (IMROZ) study design: Isatuximab plus bortezomib (V), lenalidomide (R), and dexamethasone (d) vs. VRd in transplant-ineligible patients (pts) with newly diagnosed multiple myeloma (NDMM). J. Clin. Oncol. 2018, 36, TPS8055. [CrossRef]

56. Ocio, E.M.; Rodríguez Otero, P.; Bringhen, S.; Oliva, S.; Nogai, A.; Attal, M.; Moreau, P.; Martinez-Lopez, J.; Le Roux, N.; Macé, S.; et al. Updates from a phase Ib study of isatuximab (Isa), bortezomib (V) and dexamethasone (D) plus cyclophosphamide (C) or lenalidomide (R) in transplant-ineligible, newly diagnosed multiple myeloma (NDMM). J. Clin. Oncol. 2020, 38, 8529. [CrossRef]

57. Boxhammer, R.; Weirather, J.; Steidl, S.; Endell, J. MOR202, a Human Anti-CD38 Monoclonal Antibody, Mediates Potent Tumoricidal Activity In Vivo and Shows Synergistic Efficacy in Combination with Different Antineoplastic Compounds. Blood 2015, 126, 3015. [CrossRef]

58. Raab, M.S.; Engelhardt, M.; Blank, A.; Goldschmidt, H.; Agis, H.; Blau, I.W.; Einsele, H.; Ferstl, B.; Schub, N.; Röllig, C.; et al. MOR202, a novel anti-CD38 monoclonal antibody, in patients with relapsed or refractory multiple myeloma: A first-in-human, multicentre, phase 1-2a trial. Lancet Haematol. 2020, 7, e381-e394. [CrossRef]

59. Krishnan, A.Y.; Patel, K.K.; Hari, P.; Jagannath, S.; Niesvizky, R.; Silbermann, R.W.; Berg, D.T.; Li, Q.; Allikmets, K.; StockerlGoldstein, K. A phase Ib study of TAK-079, an investigational anti-CD38 monoclonal antibody (mAb) in patients with relapsed/refractory multiple myeloma (RRMM): Preliminary results. J. Clin. Oncol. 2020, 38, 8539. [CrossRef]

60. Palaiologou, M.; Delladetsima, I.; Tiniakos, D. CD138 (syndecan-1) expression in health and disease. Histol. Histopathol. 2014, 29, 177-189. [CrossRef] 
61. Ikeda, H.; Hideshima, T.; Fulciniti, M.; Lutz, R.J.; Yasui, H.; Okawa, Y.; Kiziltepe, T.; Vallet, S.; Pozzi, S.; Santo, L.; et al. The monoclonal antibody nBT062 conjugated to cytotoxic Maytansinoids has selective cytotoxicity against CD138-positive multiple myeloma cells in vitro and in vivo. Clin. Cancer Res. 2009, 15, 4028-4037. [CrossRef]

62. Erickson, H.K.; Park, P.U.; Widdison, W.C.; Kovtun, Y.V.; Garrett, L.M.; Hoffman, K.; Lutz, R.J.; Goldmacher, V.S.; Blättler, W.A. Antibody-Maytansinoid Conjugates Are Activated in Targeted Cancer Cells by Lysosomal Degradation and Linker-Dependent Intracellular Processing. Cancer Res. 2006, 66, 4426-4433. [CrossRef] [PubMed]

63. Jagannath, S.; Heffner, L.T., Jr.; Ailawadhi, S.; Munshi, N.C.; Zimmerman, T.M.; Rosenblatt, J.; Lonial, S.; Chanan-Khan, A.; Ruehle, M.; Rharbaoui, F.; et al. Indatuximab Ravtansine (BT062) Monotherapy in Patients With Relapsed and/or Refractory Multiple Myeloma. Clin. Lymphoma Myeloma Leuk. 2019, 19, 372-380. [CrossRef]

64. Kelly, K.R.; Siegel, D.S.; Chanan-Khan, A.A.; Somlo, G.; Heffner, L.T.; Jagannath, S.; Zimmerman, T.; Munshi, N.C.; Madan, S.; Mohrbacher, A.; et al. Indatuximab Ravtansine (BT062) in Combination with Low-Dose Dexamethasone and Lenalidomide or Pomalidomide: Clinical Activity in Patients with Relapsed/Refractory Multiple Myeloma. Blood 2016, 128, 4486. [CrossRef]

65. Tai, Y.-T.; Acharya, C.; An, G.; Moschetta, M.; Zhong, M.Y.; Feng, X.; Cea, M.; Cagnetta, A.; Wen, K.; van Eenennaam, H.; et al. APRIL and BCMA promote human multiple myeloma growth and immunosuppression in the bone marrow microenvironment. Blood 2016, 127, 3225-3236. [CrossRef] [PubMed]

66. Coquery, C.M.; Erickson, L.D. Regulatory roles of the tumor necrosis factor receptor BCMA. Crit. Rev. Immunol. 2012, 32, 287-305. [CrossRef] [PubMed]

67. Carpenter, R.O.; Evbuomwan, M.O.; Pittaluga, S.; Rose, J.J.; Raffeld, M.; Yang, S.; Gress, R.E.; Hakim, F.T.; Kochenderfer, J.N. B-cell maturation antigen is a promising target for adoptive T-cell therapy of multiple myeloma. Clin. Cancer Res. 2013, 19, 2048-2060. [CrossRef] [PubMed]

68. Ghermezi, M.; Li, M.; Vardanyan, S.; Harutyunyan, N.M.; Gottlieb, J.; Berenson, A.; Spektor, T.M.; Andreu-Vieyra, C.; Petraki, S.; Sanchez, E.; et al. Serum B-cell maturation antigen: A novel biomarker to predict outcomes for multiple myeloma patients. Haematologica 2017, 102, 785-795. [CrossRef]

69. O'Connor, B.P.; Raman, V.S.; Erickson, L.D.; Cook, W.J.; Weaver, L.K.; Ahonen, C.; Lin, L.L.; Mantchev, G.T.; Bram, R.J.; Noelle, R.J. BCMA is essential for the survival of long-lived bone marrow plasma cells. J. Exp. Med. 2004, 199, 91-98. [CrossRef]

70. Low, M.S.Y.; Brodie, E.J.; Fedele, P.L.; Liao, Y.; Grigoriadis, G.; Strasser, A.; Kallies, A.; Willis, S.N.; Tellier, J.; Shi, W.; et al. IRF4 Activity Is Required in Established Plasma Cells to Regulate Gene Transcription and Mitochondrial Homeostasis. Cell Rep. 2019, 29, 2634-2645.e2635. [CrossRef]

71. Shen, X.; Guo, Y.; Qi, J.; Shi, W.; Wu, X.; Ju, S. Binding of B-cell maturation antigen to B-cell activating factor induces survival of multiple myeloma cells by activating Akt and JNK signaling pathways. Cell Biochem. Funct. 2016, 34, 104-110. [CrossRef] [PubMed]

72. Ryan, M.C.; Hering, M.; Peckham, D.; McDonagh, C.F.; Brown, L.; Kim, K.M.; Meyer, D.L.; Zabinski, R.F.; Grewal, I.S.; Carter, P.J. Antibody targeting of B-cell maturation antigen on malignant plasma cells. Mol. Cancer Ther. 2007, 6, 3009-3018. [CrossRef] [PubMed]

73. Tai, Y.T.; Mayes, P.A.; Acharya, C.; Zhong, M.Y.; Cea, M.; Cagnetta, A.; Craigen, J.; Yates, J.; Gliddon, L.; Fieles, W.; et al. Novel anti-B-cell maturation antigen antibody-drug conjugate (GSK2857916) selectively induces killing of multiple myeloma. Blood 2014, 123, 3128-3138. [CrossRef] [PubMed]

74. Lee, L.; Bounds, D.; Paterson, J.; Herledan, G.; Sully, K.; Seestaller-Wehr, L.M.; Fieles, W.E.; Tunstead, J.; McCahon, L.; Germaschewski, F.M.; et al. Evaluation of B cell maturation antigen as a target for antibody drug conjugate mediated cytotoxicity in multiple myeloma. Br. J. Haematol. 2016, 174, 911-922. [CrossRef]

75. Trudel, S.; Lendvai, N.; Popat, R.; Voorhees, P.M.; Reeves, B.; Libby, E.N.; Richardson, P.G.; Hoos, A.; Gupta, I.; Bragulat, V.; et al Antibody-drug conjugate, GSK2857916, in relapsed/refractory multiple myeloma: An update on safety and efficacy from dose expansion phase I study. Blood Cancer J. 2019, 9, 37. [CrossRef]

76. Lonial, S.; Lee, H.C.; Badros, A.; Trudel, S.; Nooka, A.K.; Chari, A.; Abdallah, A.-O.; Callander, N.; Lendvai, N.; Sborov, D.; et al. Belantamab mafodotin for relapsed or refractory multiple myeloma (DREAMM-2): A two-arm, randomised, open-label, phase 2 study. Lancet Oncol. 2020, 21, 207-221. [CrossRef]

77. Nooka, A.K.; Stockerl-Goldstein, K.; Quach, H.; Forbes, A.; Mateos, M.-V.; Khot, A.; Tan, A.; Abonour, R.; Chopra, B.; Rogers, R.; et al. DREAMM-6: Safety and tolerability of belantamab mafodotin in combination with bortezomib/dexamethasone in relapsed/refractory multiple myeloma (RRMM). J. Clin. Oncol. 2020, 38, 8502. [CrossRef]

78. Dahlén, E.; Veitonmäki, N.; Norlén, P. Bispecific antibodies in cancer immunotherapy. Ther. Adv. Vaccines Immunother. 2018, 6, 3-17. [CrossRef]

79. Caraccio, C.; Krishna, S.; Phillips, D.J.; Schürch, C.M. Bispecific Antibodies for Multiple Myeloma: A Review of Targets, Drugs, Clinical Trials, and Future Directions. Front. Immunol. 2020, 11, 501. [CrossRef]

80. Garfall, A.L.; Usmani, S.Z.; Mateos, M.-V.; Nahi, H.; van de Donk, N.W.C.J.; San-Miguel, J.F.; Oriol Rocafiguera, A.; Rosinol, L.; Chari, A.; Bhutani, M.; et al. Updated Phase 1 Results of Teclistamab, a B-Cell Maturation Antigen (BCMA) x CD3 Bispecific Antibody, in Relapsed and/or Refractory Multiple Myeloma (RRMM). Blood 2020, 136, 27. [CrossRef] 
81. Harrison, S.J.; Minnema, M.C.; Lee, H.C.; Spencer, A.; Kapoor, P.; Madduri, D.; Larsen, J.; Ailawadhi, S.; Kaufman, J.L.; Raab, M.S.; et al. A Phase 1 First in Human (FIH) Study of AMG 701, an Anti-B-Cell Maturation Antigen (BCMA) Half-Life Extended (HLE) BiTE ${ }^{\circledR}$ (bispecific T-cell engager) Molecule, in Relapsed/Refractory (RR) Multiple Myeloma (MM). Blood 2020, 136, 28-29. [CrossRef]

82. Miliotou, A.N.; Papadopoulou, L.C. CAR T-cell Therapy: A New Era in Cancer Immunotherapy. Curr. Pharm. Biotechnol. 2018, 19, 5-18. [CrossRef]

83. Maude, S.L.; Laetsch, T.W.; Buechner, J.; Rives, S.; Boyer, M.; Bittencourt, H.; Bader, P.; Verneris, M.R.; Stefanski, H.E.; Myers, G.D.; et al. Tisagenlecleucel in Children and Young Adults with B-Cell Lymphoblastic Leukemia. N. Engl. J. Med. 2018, 378, 439-448. [CrossRef]

84. Neelapu, S.S.; Locke, F.L.; Bartlett, N.L.; Lekakis, L.J.; Miklos, D.B.; Jacobson, C.A.; Braunschweig, I.; Oluwole, O.O.; Siddiqi, T.; Lin, Y.; et al. Axicabtagene Ciloleucel CAR T-Cell Therapy in Refractory Large B-Cell Lymphoma. N. Engl. J. Med. 2017, 377, 2531-2544. [CrossRef]

85. Roex, G.; Timmers, M.; Wouters, K.; Campillo-Davo, D.; Flumens, D.; Schroyens, W.; Chu, Y.; Berneman, Z.N.; Lion, E.; Luo, F.; et al. Safety and clinical efficacy of BCMA CAR-T-cell therapy in multiple myeloma. J. Hematol. Oncol. 2020, 13, 164. [CrossRef]

86. Mailankody, S.; Matous, J.V.; Liedtke, M.; Sidana, S.; Malik, S.; Nath, R.; Oluwole, O.O.; Karski, E.E.; Lovelace, W.; Zhou, X.; et al. Universal: An Allogeneic First-in-Human Study of the Anti-Bcma ALLO-715 and the Anti-CD52 ALLO-647 in Relapsed/Refractory Multiple Myeloma. Blood 2020, 136, 24-25. [CrossRef]

87. Alsina, M.; Shah, N.; Raje, N.S.; Jagannath, S.; Madduri, D.; Kaufman, J.L.; Siegel, D.S.; Munshi, N.C.; Rosenblatt, J.; Lin, Y.; et al. Updated Results from the Phase I CRB-402 Study of Anti-Bcma CAR-T Cell Therapy bb21217 in Patients with Relapsed and Refractory Multiple Myeloma: Correlation of Expansion and Duration of Response with T Cell Phenotypes. Blood 2020, 136, 25-26. [CrossRef]

88. Lin, Y.; Raje, N.S.; Berdeja, J.G.; Siegel, D.S.; Jagannath, S.; Madduri, D.; Liedtke, M.; Rosenblatt, J.; Maus, M.V.; Massaro, M.; et al. Idecabtagene Vicleucel (ide-cel, bb2121), a BCMA-Directed CAR T Cell Therapy, in Patients with Relapsed and Refractory Multiple Myeloma: Updated Results from Phase 1 CRB-401 Study. Blood 2020, 136, 26-27. [CrossRef]

89. Hao, S.; Jin, J.; Jiang, S.; Li, Z.; Zhang, W.; Yang, M.; Yu, K.; Wang, W.; Chen, L.; Meng, H.; et al. Two-Year Follow-up of InvestigatorInitiated Phase 1 Trials of the Safety and Efficacy of Fully Human Anti-Bcma CAR T Cells (CT053) in Relapsed/Refractory Multiple Myeloma. Blood 2020, 136, 27-28. [CrossRef]

90. Kumar, S.K.; Baz, R.C.; Orlowski, R.Z.; Anderson, L.D., Jr.; Ma, H.; Shrewsbury, A.; Croghan, K.A.; Bilgi, M.; Kansagra, A.; Kapoor, P.; et al. Results from Lummicar-2: A Phase 1b/2 Study of Fully Human B-Cell Maturation Antigen-Specific CAR T Cells (CT053) in Patients with Relapsed and/or Refractory Multiple Myeloma. Blood 2020, 136, 28-29. [CrossRef]

91. Costello, C.L.; Cohen, A.D.; Patel, K.K.; Ali, S.S.; Berdeja, J.G.; Shah, N.; Ganguly, S.; Kocoglu, M.H.; Abedi, M.; Ostertag, E.M.; et al. Phase 1/2 Study of the Safety and Response of P-BCMA-101 CAR-T Cells in Patients with Relapsed/Refractory (r/r) Multiple Myeloma (MM) (PRIME) with Novel Therapeutic Strategies. Blood 2020, 136, 29-30. [CrossRef]

92. Madduri, D.; Berdeja, J.G.; Usmani, S.Z.; Jakubowiak, A.; Agha, M.; Cohen, A.D.; Stewart, A.K.; Hari, P.; Htut, M.; O’Donnell, E.; et al. CARTITUDE-1: Phase 1b/2 Study of Ciltacabtagene Autoleucel, a B-Cell Maturation Antigen-Directed Chimeric Antigen Receptor T Cell Therapy, in Relapsed/Refractory Multiple Myeloma. Blood 2020, 136, 22-25. [CrossRef]

93. Jiang, H.; Dong, B.; Gao, L.; Liu, L.; Ge, J.; He, A.; Du, J., Jr.; Li, L.; Lu, J.; Chen, X.; et al. Clinical Results of a Multicenter Study of the First-in-Human Dual BCMA and CD19 Targeted Novel Platform Fast CAR-T Cell Therapy for Patients with Relapsed/Refractory Multiple Myeloma. Blood 2020, 136, 25-26. [CrossRef]

94. An, G.; Sui, W.; Wang, T.; Qu, X.; Zhang, X.; Yang, J.; Zhang, Y.; Zhang, L.; Zhu, J.; Zheng, C.; et al. An Anti-Bcma CAR T-Cell Therapy (C-CAR088) Shows Promising Safety and Efficacy Profile in Relapsed or Refractory Multiple Myeloma. Blood 2020, 136, 29-30. [CrossRef]

95. Cannons, J.L.; Tangye, S.G.; Schwartzberg, P.L. SLAM family receptors and SAP adaptors in immunity. Annu. Rev. Immunol. 2011, 29, 665-705. [CrossRef] [PubMed]

96. Hsi, E.D.; Steinle, R.; Balasa, B.; Szmania, S.; Draksharapu, A.; Shum, B.P.; Huseni, M.; Powers, D.; Nanisetti, A.; Zhang, Y.; et al. CS1, a potential new therapeutic antibody target for the treatment of multiple myeloma. Clin. Cancer Res. 2008, 14, $2775-2784$. [CrossRef]

97. Tai, Y.T.; Dillon, M.; Song, W.; Leiba, M.; Li, X.F.; Burger, P.; Lee, A.I.; Podar, K.; Hideshima, T.; Rice, A.G.; et al. Anti-CS1 humanized monoclonal antibody HuLuc63 inhibits myeloma cell adhesion and induces antibody-dependent cellular cytotoxicity in the bone marrow milieu. Blood 2008, 112, 1329-1337. [CrossRef]

98. Tai, Y.-T.; Soydan, E.; Song, W.; Fulciniti, M.; Kim, K.; Hong, F.; Li, X.-F.; Burger, P.; Rumizen, M.J.; Nahar, S.; et al. CS1 promotes multiple myeloma cell adhesion, clonogenic growth, and tumorigenicity via c-maf-mediated interactions with bone marrow stromal cells. Blood 2009, 113, 4309-4318. [CrossRef]

99. Ishibashi, M.; Soeda, S.; Sasaki, M.; Handa, H.; Imai, Y.; Tanaka, N.; Tanosaki, S.; Ito, S.; Odajima, T.; Sugimori, H.; et al. Clinical impact of serum soluble SLAMF7 in multiple myeloma. Oncotarget 2018, 9, 34784-34793. [CrossRef]

100. Collins, S.M.; Bakan, C.E.; Swartzel, G.D.; Hofmeister, C.C.; Efebera, Y.A.; Kwon, H.; Starling, G.C.; Ciarlariello, D.; Bhaskar, S.; Briercheck, E.L.; et al. Elotuzumab directly enhances NK cell cytotoxicity against myeloma via CS1 ligation: Evidence for augmented NK cell function complementing ADCC. Cancer Immunol. Immunother. 2013, 62, 1841-1849. [CrossRef] 
101. Zonder, J.A.; Mohrbacher, A.F.; Singhal, S.; van Rhee, F.; Bensinger, W.I.; Ding, H.; Fry, J.; Afar, D.E.; Singhal, A.K. A phase 1, multicenter, open-label, dose escalation study of elotuzumab in patients with advanced multiple myeloma. Blood 2012, 120, 552-559. [CrossRef]

102. Jakubowiak, A.J.; Benson, D.M.; Bensinger, W.; Siegel, D.S.; Zimmerman, T.M.; Mohrbacher, A.; Richardson, P.G.; Afar, D.E.; Singhal, A.K.; Anderson, K.C. Phase I trial of anti-CS1 monoclonal antibody elotuzumab in combination with bortezomib in the treatment of relapsed/refractory multiple myeloma. J. Clin. Oncol. 2012, 30, 1960-1965. [CrossRef]

103. Lonial, S.; Vij, R.; Harousseau, J.L.; Facon, T.; Moreau, P.; Mazumder, A.; Kaufman, J.L.; Leleu, X.; Tsao, L.C.; Westland, C.; et al. Elotuzumab in combination with lenalidomide and low-dose dexamethasone in relapsed or refractory multiple myeloma. J. Clin. Oncol. 2012, 30, 1953-1959. [CrossRef] [PubMed]

104. Lonial, S.; Dimopoulos, M.; Palumbo, A.; White, D.; Grosicki, S.; Spicka, I.; Walter-Croneck, A.; Moreau, P.; Mateos, M.V.; Magen, H.; et al. Elotuzumab Therapy for Relapsed or Refractory Multiple Myeloma. N. Engl. J. Med. 2015, 373, 621-631. [CrossRef] [PubMed]

105. Dimopoulos, M.A.; Lonial, S.; White, D.; Moreau, P.; Weisel, K.; San-Miguel, J.; Shpilberg, O.; Grosicki, S.; Špička, I.; WalterCroneck, A.; et al. Elotuzumab, lenalidomide, and dexamethasone in RRMM: Final overall survival results from the phase 3 randomized ELOQUENT-2 study. Blood Cancer J. 2020, 10, 91. [CrossRef]

106. Dimopoulos, M.A.; Dytfeld, D.; Grosicki, S.; Moreau, P.; Takezako, N.; Hori, M.; Leleu, X.; LeBlanc, R.; Suzuki, K.; Raab, M.S.; et al. Elotuzumab plus Pomalidomide and Dexamethasone for Multiple Myeloma. N. Engl. J. Med. 2018, 379, 1811-1822. [CrossRef] [PubMed]

107. Jakubowiak, A.; Offidani, M.; Pégourie, B.; De La Rubia, J.; Garderet, L.; Laribi, K.; Bosi, A.; Marasca, R.; Laubach, J.; Mohrbacher, A.; et al. Randomized phase 2 study: Elotuzumab plus bortezomib/dexamethasone vs. bortezomib/dexamethasone for relapsed/refractory MM. Blood 2016, 127, 2833-2840. [CrossRef]

108. Usmani, S.Z.; Hoering, A.; Ailawadhi, S.; Sexton, R.; Lipe, B.; Hita, S.F.; Valent, J.; Rosenzweig, M.; Zonder, J.A.; Dhodapkar, M.; et al. Bortezomib, lenalidomide, and dexamethasone with or without elotuzumab in patients with untreated, high-risk multiple myeloma (SWOG-1211): Primary analysis of a randomised, phase 2 trial. Lancet Haematol. 2021, 8, e45-e54. [CrossRef]

109. Tan, D.S.; Bedard, P.L.; Kuruvilla, J.; Siu, L.L.; Razak, A.R. Promising SINEs for embargoing nuclear-cytoplasmic export as an anticancer strategy. Cancer Discov. 2014, 4, 527-537. [CrossRef] [PubMed]

110. Schmidt, J.; Braggio, E.; Kortuem, K.M.; Egan, J.B.; Zhu, Y.X.; Xin, C.S.; Tiedemann, R.E.; Palmer, S.E.; Garbitt, V.M.; McCauley, D.; et al. Genome-wide studies in multiple myeloma identify XPO1/CRM1 as a critical target validated using the selective nuclear export inhibitor KPT-276. Leukemia 2013, 27, 2357-2365. [CrossRef]

111. Tai, Y.T.; Landesman, Y.; Acharya, C.; Calle, Y.; Zhong, M.Y.; Cea, M.; Tannenbaum, D.; Cagnetta, A.; Reagan, M.; Munshi, A.A.; et al. CRM1 inhibition induces tumor cell cytotoxicity and impairs osteoclastogenesis in multiple myeloma: Molecular mechanisms and therapeutic implications. Leukemia 2014, 28, 155-165. [CrossRef]

112. Vogl, D.T.; Dingli, D.; Cornell, R.F.; Huff, C.A.; Jagannath, S.; Bhutani, D.; Zonder, J.; Baz, R.; Nooka, A.; Richter, J.; et al. Selective Inhibition of Nuclear Export With Oral Selinexor for Treatment of Relapsed or Refractory Multiple Myeloma. J. Clin. Oncol. 2018, 36, 859-866. [CrossRef]

113. Kashyap, T.; Argueta, C.; Aboukameel, A.; Unger, T.J.; Klebanov, B.; Mohammad, R.M.; Muqbil, I.; Azmi, A.S.; Drolen, C.; Senapedis, W.; et al. Selinexor, a Selective Inhibitor of Nuclear Export (SINE) compound, acts through NF- $\kappa B$ deactivation and combines with proteasome inhibitors to synergistically induce tumor cell death. Oncotarget 2016, 7, 78883-78895. [CrossRef]

114. Bahlis, N.J.; Sutherland, H.; White, D.; Sebag, M.; Lentzsch, S.; Kotb, R.; Venner, C.P.; Gasparetto, C.; Del Col, A.; Neri, P.; et al. Selinexor plus low-dose bortezomib and dexamethasone for patients with relapsed or refractory multiple myeloma. Blood 2018, 132, 2546-2554. [CrossRef]

115. Dimopoulos, M.A.; Delimpasi, S.; Simonova, M.; Spicka, I.; Pour, L.; Kryachok, I.; Gavriatopoulou, M.; Pylypenko, H.; Auner, H.W.; Leleu, X.; et al. Weekly selinexor, bortezomib, and dexamethasone (SVd) versus twice weekly bortezomib and dexamethasone $(\mathrm{Vd})$ in patients with multiple myeloma (MM) after one to three prior therapies: Initial results of the phase III BOSTON study. J. Clin. Oncol. 2020, 38, 8501. [CrossRef]

116. Gasparetto, C.; Lipe, B.; Tuchman, S.; Callander, N.S.; Lentzsch, S.; Baljevic, M.; Rossi, A.C.; Bahlis, N.J.; White, D.; Chen, C.; et al. Once weekly selinexor, carfilzomib, and dexamethasone (SKd) in patients with relapsed/refractory multiple myeloma (MM). J. Clin. Oncol. 2020, 38, 8530. [CrossRef]

117. Chen, C.I.; Bahlis, N.J.; Gasparetto, C.; Tuchman, S.A.; Lipe, B.; Baljevic, M.; Kotb, R.; Sutherland, H.J.; Bensinger, W.I.; Sebag, M.; et al. Selinexor in Combination with Pomalidomide and Dexamethasone (SPd) for Treatment of Patients with Relapsed Refractory Multiple Myeloma (RRMM). Blood 2020, 136, 18-19. [CrossRef]

118. Touzeau, C.; Maciag, P.; Amiot, M.; Moreau, P. Targeting Bcl-2 for the treatment of multiple myeloma. Leukemia 2018, 32, 1899-1907. [CrossRef] [PubMed]

119. Fedele, P.L.; Liao, Y.; Gong, J.N.; Yao, Y.; van Delft, M.F.; Low, M.S.Y.; Tai, L.; Herold, M.J.; Jackson, J.T.; Teh, C.E.; et al. The transcription factor IRF4 represses proapoptotic BMF and BIM to licence multiple myeloma survival. Leukemia 2020. [CrossRef] [PubMed]

120. Low, M.; Infantino, S.; Grigoriadis, G.; Tarlinton, D. Targeting plasma cells: Are we any closer to a panacea for diseases of antibody-secreting cells? Immunol. Rev. 2016, 270, 78-94. [CrossRef] 
121. Teh, C.E.; Gong, J.-N.; Segal, D.; Tan, T.; Vandenberg, C.J.; Fedele, P.L.; Low, M.S.Y.; Grigoriadis, G.; Harrison, S.J.; Strasser, A.; et al. Deep profiling of apoptotic pathways with mass cytometry identifies a synergistic drug combination for killing myeloma cells. Cell Death Differ. 2020, 27, 2217-2233. [CrossRef]

122. Mihalyova, J.; Jelinek, T.; Growkova, K.; Hrdinka, M.; Simicek, M.; Hajek, R. Venetoclax: A new wave in hematooncology. Exp. Hematol. 2018, 61, 10-25. [CrossRef] [PubMed]

123. Kumar, S.; Kaufman, J.L.; Gasparetto, C.; Mikhael, J.; Vij, R.; Pegourie, B.; Benboubker, L.; Facon, T.; Amiot, M.; Moreau, P.; et al. Efficacy of venetoclax as targeted therapy for relapsed/refractory $t(11 ; 14)$ multiple myeloma. Blood 2017, 130, 2401-2409. [CrossRef] [PubMed]

124. Kaufman, J.L.; Gasparetto, C.; Schjesvold, F.H.; Moreau, P.; Touzeau, C.; Facon, T.; Boise, L.H.; Alzate, S.; Macartney, T.; Pesko, J.; et al. Phase I/II Study Evaluating the Safety and Efficacy of Venetoclax in Combination with Dexamethasone As Targeted Therapy for Patients with $\mathrm{t}(11 ; 14)$ Relapsed/Refractory Multiple Myeloma. Blood 2019, 134, 926. [CrossRef]

125. Mateos, M.-V.; Moreau, P.; Dimopoulos, M.A.; Hong, W.-J.; Cooper, S.; Yu, Y.; Jalaluddin, M.; Ross, J.A.; Karve, S.; Coppola, S.; et al. A phase III, randomized, multicenter, open-label study of venetoclax or pomalidomide in combination with dexamethasone in patients with $\mathrm{t}(11 ; 14)$-positive relapsed/refractory multiple myeloma. J. Clin. Oncol. 2020, 38, TPS8554. [CrossRef]

126. Punnoose, E.A.; Leverson, J.D.; Peale, F.; Boghaert, E.R.; Belmont, L.D.; Tan, N.; Young, A.; Mitten, M.; Ingalla, E.; Darbonne, W.C.; et al. Expression Profile of BCL-2, BCL-XL, and MCL-1 Predicts Pharmacological Response to the BCL-2 Selective Antagonist Venetoclax in Multiple Myeloma Models. Mol. Cancer Ther. 2016, 15, 1132-1144. [CrossRef] [PubMed]

127. Kumar, S.K.; Harrison, S.J.; Cavo, M.; de la Rubia, J.; Popat, R.; Gasparetto, C.; Hungria, V.; Salwender, H.; Suzuki, K.; Kim, I.; et al. Venetoclax or placebo in combination with bortezomib and dexamethasone in patients with relapsed or refractory multiple myeloma (BELLINI): A randomised, double-blind, multicentre, phase 3 trial. Lancet Oncol. 2020, 21, 1630-1642. [CrossRef]

128. San-Miguel, J.F.; Hungria, V.T.M.; Yoon, S.-S.; Beksac, M.; Dimopoulos, M.A.; Elghandour, A.; Jedrzejczak, W.W.; Günther, A.; Nakorn, T.N.; Siritanaratkul, N.; et al. Panobinostat plus bortezomib and dexamethasone versus placebo plus bortezomib and dexamethasone in patients with relapsed or relapsed and refractory multiple myeloma: A multicentre, randomised, double-blind phase 3 trial. Lancet Oncol. 2014, 15, 1195-1206. [CrossRef]

129. Laubach, J.P.; Schjesvold, F.; Mariz, M.; Dimopoulos, M.A.; Lech-Maranda, E.; Spicka, I.; Hungria, V.T.M.; Shelekhova, T.; Abdo, A.; Jacobasch, L.; et al. Efficacy and safety of oral panobinostat plus subcutaneous bortezomib and oral dexamethasone in patients with relapsed or relapsed and refractory multiple myeloma (PANORAMA 3): An open-label, randomised, phase 2 study. Lancet Oncol. 2021, 22, 142-154. [CrossRef]

130. Vogl, D.T.; Raje, N.; Jagannath, S.; Richardson, P.; Hari, P.; Orlowski, R.; Supko, J.G.; Tamang, D.; Yang, M.; Jones, S.S.; et al. Ricolinostat, the First Selective Histone Deacetylase 6 Inhibitor, in Combination with Bortezomib and Dexamethasone for Relapsed or Refractory Multiple Myeloma. Clin. Cancer Res. 2017, 23, 3307-3315. [CrossRef] [PubMed]

131. Yee, A.J.; Bensinger, W.I.; Supko, J.G.; Voorhees, P.M.; Berdeja, J.G.; Richardson, P.G.; Libby, E.N.; Wallace, E.E.; Birrer, N.E.; Burke, J.N.; et al. Ricolinostat plus lenalidomide, and dexamethasone in relapsed or refractory multiple myeloma: A multicentre phase 1b trial. Lancet Oncol. 2016, 17, 1569-1578. [CrossRef]

132. Li, Z.; Qi, C.-F.; Shin, D.-M.; Zingone, A.; Newbery, H.J.; Kovalchuk, A.L.; Abbott, C.M.; Morse, H.C., 3rd. Eef1a2 promotes cell growth, inhibits apoptosis and activates JAK/STAT and AKT signaling in mouse plasmacytomas. PLoS ONE 2010, 5 , e10755. [CrossRef]

133. Losada, A.; Muñoz-Alonso, M.J.; García, C.; Sánchez-Murcia, P.A.; Martínez-Leal, J.F.; Domínguez, J.M.; Lillo, M.P.; Gago, F.; Galmarini, C.M. Translation Elongation Factor eEF1A2 is a Novel Anticancer Target for the Marine Natural Product Plitidepsin. Sci. Rep. 2016, 6, 35100. [CrossRef] [PubMed]

134. González-Santiago, L.; Suárez, Y.; Zarich, N.; Muñoz-Alonso, M.J.; Cuadrado, A.; Martínez, T.; Goya, L.; Iradi, A.; Sáez-Tormo, G.; Maier, J.V.; et al. Aplidin induces JNK-dependent apoptosis in human breast cancer cells via alteration of glutathione homeostasis, Rac1 GTPase activation, and MKP-1 phosphatase downregulation. Cell Death Differ. 2006, 13, 1968-1981. [CrossRef] [PubMed]

135. Mateos, M.; Cibeira, M.; Richardson, P.; Prosper, F.; Oriol, A.; Rubia, J.; Lahuerta, J.; Garcia-Sanz, R.; Extremera, S.; Szyldergemajn, S.; et al. Phase II Clinical and Pharmacokinetic Study of Plitidepsin 3-Hour Infusion Every Two Weeks Alone or with Dexamethasone in Relapsed and Refractory Multiple Myeloma. Clin. Cancer Res. Off. J. Am. Assoc. Cancer Res. 2010, 16, 3260-3269. [CrossRef] [PubMed]

136. Spicka, I.; Ocio, E.M.; Oakervee, H.E.; Greil, R.; Banh, R.H.; Huang, S.Y.; D’Rozario, J.M.; Dimopoulos, M.A.; Martínez, S.; Extremera, S.; et al. Randomized phase III study (ADMYRE) of plitidepsin in combination with dexamethasone vs. dexamethasone alone in patients with relapsed/refractory multiple myeloma. Ann. Hematol. 2019, 98, 2139-2150. [CrossRef]

137. Ocio, E.M.; Mateos, M.-V.; Prosper, F.; Martin, J.; Rocafiguera, A.O.; Jarque, I.; Iglesias, R.; Motlloo, C.; Sole, M.; Rodriguez-Otero, P.; et al. Phase I study of plitidepsin in combination with bortezomib and dexamethasone in patients with relapsed and/or refractory multiple myeloma. J. Clin. Oncol. 2016, 34, 8006. [CrossRef]

138. Weiskopf, K. Cancer immunotherapy targeting the CD47/SIRP $\alpha$ axis. Eur. J. Cancer 2017, 76, 100-109. [CrossRef] [PubMed]

139. Sun, J.; Muz, B.; Alhallak, K.; Markovic, M.; Gurley, S.; Wang, Z.; Guenthner, N.; Wasden, K.; Fiala, M.; King, J.; et al. Targeting CD47 as a Novel Immunotherapy for Multiple Myeloma. Cancers 2020, 12, 305. [CrossRef]

140. Wilson, W.C.; Richards, J.; Puro, R.J.; Andrejeva, G.; Capoccia, B.J.; Donio, M.J.; Hiebsch, R.R.; Chakraborty, P.; Sung, V.; Pereira, D.S. AO-176, a Highly Differentiated Clinical Stage Anti-CD47 Antibody, Exerts Potent Anti-Tumor Activity in Preclinical Models of Multiple Myeloma As a Single Agent and in Combination with Approved Therapeutics. Blood 2020, 136, 3-4. [CrossRef] 
141. Mateos, M.-V.; Blacklock, H.; Schjesvold, F.; Oriol, A.; Simpson, D.; George, A.; Goldschmidt, H.; Larocca, A.; Chanan-Khan, A.; Sherbenou, D.; et al. Pembrolizumab plus pomalidomide and dexamethasone for patients with relapsed or refractory multiple myeloma (KEYNOTE-183): A randomised, open-label, phase 3 trial. Lancet Haematol. 2019, 6, e459-e469. [CrossRef]

142. Usmani, S.Z.; Schjesvold, F.; Oriol, A.; Karlin, L.; Cavo, M.; Rifkin, R.M.; Yimer, H.A.; LeBlanc, R.; Takezako, N.; McCroskey, R.D.; et al. Pembrolizumab plus lenalidomide and dexamethasone for patients with treatment-naive multiple myeloma (KEYNOTE-185): A randomised, open-label, phase 3 trial. Lancet Haematol. 2019, 6, e448-e458. [CrossRef]

143. Smith, E.L.; Harrington, K.; Staehr, M.; Masakayan, R.; Jones, J.; Long, T.J.; Ng, K.Y.; Ghoddusi, M.; Purdon, T.J.; Wang, X.; et al. GPRC5D is a target for the immunotherapy of multiple myeloma with rationally designed CAR T cells. Sci. Transl. Med. 2019, 11, eaau7746. [CrossRef]

144. Chari, A.; Berdeja, J.G.; Oriol, A.; van de Donk, N.W.C.J.; Rodriguez, P.; Askari, E.; Mateos, M.-V.; Minnema, M.C.; Verona, R.; Girgis, S.; et al. A Phase 1, First-in-Human Study of Talquetamab, a G Protein-Coupled Receptor Family C Group 5 Member D (GPRC5D) x CD3 Bispecific Antibody, in Patients with Relapsed and/or Refractory Multiple Myeloma (RRMM). Blood 2020, 136, 40-41. [CrossRef]

145. Elkins, K.; Zheng, B.; Go, M.; Slaga, D.; Du, C.; Scales, S.J.; Yu, S.F.; McBride, J.; de Tute, R.; Rawstron, A.; et al. FcRL5 as a target of antibody-drug conjugates for the treatment of multiple myeloma. Mol. Cancer Ther. 2012, 11, 2222-2232. [CrossRef] [PubMed]

146. Hatzivassiliou, G.; Miller, I.; Takizawa, J.; Palanisamy, N.; Rao, P.H.; Iida, S.; Tagawa, S.; Taniwaki, M.; Russo, J.; Neri, A.; et al. IRTA1 and IRTA2, novel immunoglobulin superfamily receptors expressed in B cells and involved in chromosome 1q21 abnormalities in B cell malignancy. Immunity 2001, 14, 277-289. [CrossRef]

147. Stewart, A.K.; Krishnan, A.Y.; Singhal, S.; Boccia, R.V.; Patel, M.R.; Niesvizky, R.; Chanan-Khan, A.A.; Ailawadhi, S.; Brumm, J.; Mundt, K.E.; et al. Phase I study of the anti-FcRH5 antibody-drug conjugate DFRF4539A in relapsed or refractory multiple myeloma. Blood Cancer J. 2019, 9, 17. [CrossRef] [PubMed]

148. Li, J.; Stagg, N.J.; Johnston, J.; Harris, M.J.; Menzies, S.A.; DiCara, D.; Clark, V.; Hristopoulos, M.; Cook, R.; Slaga, D.; et al. Membrane-Proximal Epitope Facilitates Efficient T Cell Synapse Formation by Anti-FcRH5/CD3 and Is a Requirement for Myeloma Cell Killing. Cancer Cell 2017, 31, 383-395. [CrossRef] 